\title{
Dental Implant Surfaces - Physicochemical Properties, Biological Performance, and Trends
}

\author{
Ahmed M. Ballo, ${ }^{1,2}$, Omar Omar ${ }^{1,2}$, Wei Xia ${ }^{2,3}$ and Anders Palmquist ${ }^{1,2}$ \\ ${ }^{1}$ Department of Biomaterials, Institute of Clinical Sciences, \\ The Sahlgrenska Academy, University of Gothenburg \\ 2Biomatcell VINN Excellent Center of Biomaterials and Cell Therapy \\ ${ }^{3}$ Angstrom Laboratory, Department of Engineering Sciences, Uppsala University \\ ${ }^{1,2}$ Gothenburg \\ ${ }^{3}$ Uppsala, \\ Sweden
}

\section{Introduction}

Pure titanium and titanium alloys are well established standard materials in dental implants because of their favorable combination of mechanical strength, chemical stability, and biocompatibility (Brunette et al., 2001). Integration of titanium implants with the surrounding bone is critical for successful bone regeneration and healing of dental implant. The concept of osseointegration was discovered by Brånemark and his co-worker and, has had a dramatic influence on clinical treatment of oral implants. The first generation of successfully used clinical titanium implants, which were machined with a smooth surface texture, now approach 50 years in clinical use. Since then, implant surfaces have long been recognized to play an important role in molecular interactions, cellular response and osseointegration, and scientists all over the world have developed the second generation implants with surfaces which can accelerate and improve implant osseointegration. These second generation of clinically used implants underwent mechanical blasting coupled or not, with acid etch, bioactive coatings, anodized and, more recently, laser modified surfaces. (Cochran et al., 1998; Jansen et al., 1993; Palmquist et al., 2010; Brånemark et al., 2010 ). These implants have been extensively documented in vivo, including long-term clinical studies and experimental histological and biomechanical evaluation in animal models. For more knowledge in clinical results of commercially available implants the reader is referred to the following literature (Esposito et al., 2005; Esposito et al., 2003; Albrektsson \& Wennerberg, 2004b).

The main objective for the development of implant surface modifications is to promote osseointegration, with faster and stronger bone formation. This will likely confer better stability during the healing process, which, preferentially, will improve the clinical performance in the area of poor bone quality and quantity. Furthermore, such promotion may, in turn, accelerate the bone healing and thereby allowing immediate or early loading protocols.

Recently growing micro and nano- technology is rapidly advancing surface engineering in implant dentistry. Such advances in surface engineering technologies have resulted in more 
complicated surface properties from micro- and nanometer scales, including the morphology, chemistry, crystal structure, physical, and mechanical properties. Such surfaces, intentionally modified with respect to microscale and nanoscale features, may represent a next generation of oral implant systems if possible to transfer to complex three-dimensional geometries. Hitherto, micro- and nano-fabricated surfaces have not reached the clinical evidence stage. However, it is not known whether the improved bone response is due to surface roughness or the surface composition. Furthermore, somewhat surprisingly, there is yet not enough hard evidence (randomized clinical trials) to tell whether the second generation of the implants has a better clinical performance than the machined implants used earlier. Nevertheless, experimental evidence from in vitro and in vivo studies strongly suggests that some types of surface modifications promote a more rapid bone formation than machined surfaces.

It has been proposed that increasing osteoconductivity by these surface design strategies is related to the altered implant topography resulting in enhanced osteoblast and preosteoblast adhesion, thereby leading to accelerated bone formation (Chehroudi et al., 1992; Cooper et al., 1998). However, it is well known that titanium implantation in bone results in contact of the titanium surface with complex environment including blood components and other cells, not only the osteogenic ones. Recently, it has been shown that changes in the physicochemical properties of the titanium results in significant modulation of cell recruitment, adhesion, inflammation and bone remodelling activities in addition to regulation on bone formation response (Omar, 2010).

These different methods for implant surface modification may lead to different and unique surface properties that might affect the host-to-implant response.

This chapter reviews the state of art of development in dental implant surfaces and current trends in surface modifications that aim to accelerate the osseointegration of dental implants. This chapter also contains an overview of the most popular surface textures, chemical modifications including nano-surface design based on nanoscale modification of the implant surface, but also briefly describe the interface biology of oral implant is also discussed. Finally, it concludes with a summary and future outlook.

\section{Surface roughness of titanium implants}

Surface roughness has been identified as an important parameter for implants and its capacity for being anchored in bone tissue. There exist a variety of different manufacturing methods to increase the surface roughness of the implant, where the most commonly used are: Machining, Sandblasting, Acid etching, Anodic oxidation, Laser modification or a combination of these. Further, commercially available implants have been categorized according to the roughness value $\left(S_{a}\right)$ into 4 groups (Albrektsson \& Wennerberg, 2004a), smooth $\left(S_{a}<0.5 \mu \mathrm{m}\right)$, minimally rough $\left(S_{a}=0.5-1.0 \mu \mathrm{m}\right)$, moderately rough $\left(S_{a}=1.0-2.0 \mu \mathrm{m}\right)$ and rough $\left(S_{a}>2.0 \mu \mathrm{m}\right)$. The $S_{a}$ value represents the mean height of peaks and pits of the surface, while another important parameter is $S_{d r}$, which represents the developed surface area compared to a perfect flat area. With a larger surface area a larger contact to the bone tissue could be obtained. There exists another 50 some direct or combined surface roughness parameters (Gadelmawla et al., 2002) however, it is unknown to what extent these are important. For $S_{a}$ measurements different factors will affect the outcoming result as the type of equipment used, the area of analysis, the filtering process of the raw data, the cut-off values as well as where on the implant the measurements are performed. To obtain more 
comparable values in the literature guidelines for measurements have been published (Wennerberg \& Albrektsson, 2000). Further, it is important to acknowledge that the surface chemistry and surface phase composition of the implant surface will change by altering the surface roughness (Kasemo \& Lausmaa, 1988).

\subsection{Machined surface}

The first generation of osseointegrated implants had a relatively smooth machined surface (Branemark et al. 1969). The machined implant surface is solely turned and considered to be minimally rough (Figure 1). Different roughness values have been published using different measuring techniques. Moreover, manufacturing tools, bulk material, lubricant and machining speed will influence the resulting surface topography. Typical $S_{a}$ values for machined surfaces are 0.3-1.0 $\mu \mathrm{m}$. The surface oxide consists of a 2-10 nm thick mostly amorphous layer of $\mathrm{TiO}_{2}$ (Lausmaa, 1996). Depending on the sterilization method the oxide layer could be crystallized into rutile structure (Jarmar et al., 2008). Further, the thickness and temperature is important on the phase composition (Radegran et al., 1991).

The bone responses to machined surfaces have been extensively evaluated in different animal models as well as clinical trials. The machined surface was the first used surface in clinical dental applications and has excellent long time follow-up (Adell et al., 1981; Brånemark et al., 1977). Further, other extra oral applications with bone anchored implants use machined implants, such as bone anchored hearing aids (Brånemark et al., 2001) and bone anchored amputations prosthesis for major limbs as legs and arms (Robinson et al., 2004; Rydevik, 1997). The healing around the implant is characterized by an increase in bone-implant contact starting at the implantation while the biomechanical stability slightly decrease over the first weeks, possible due to inflammation and bone remodeling, and being fully recovered after 4 weeks in rat tibia (Brånemark et al., 1997). Endosteal down growth of bone tissue covering the implant threads occurs in the marrow cavity and reach up to $70 \%$ bone implant contact after 16 weeks in rat tibia which could be compared to clinically stable oral implants retrieved up to 16 year after implantation where the bone-implant contact was measured to 56-85\% (Sennerby et al., 1991). Eighty-five \% bone-implant contact was observed for a clinically stable bone anchored amputations prosthesis retrieved after 11 years (Palmquist et al., 2008). Further, in the latter study it was shown that hydroxyapatite forms directly at the implant surface shown in high-resolution transmission electron microscopy (TEM).

\subsection{Sandblasted surface}

Increased roughness of an implant could be achieved by blasting the surface by small particles, usually called sandblasting or grit blasting (Figure 2). When the particles hit the implant surface it will create a crater. The surface roughness is hence dependent on the bulk material, the particle material, the particle size, the particle shape, the particle speed and the density of particles. The resulting surface roughness is usually anisotropic consisting of craters and ridges and occasionally particles embedded in the surface.

The surface roughness increases with the size of the particles used (Wennerberg et al., 1992) where $25 \mu \mathrm{m}$ particles blasted surfaces were rougher than the machined surface while smoother than $75 \mu \mathrm{m}$ and $250 \mu \mathrm{m}$ blasted surfaces. Typical $S_{a}$ values are 0.5-2.0 $\mu \mathrm{m}$. Further, implants blasted with $25 \mu \mathrm{m}$ and $75 \mu \mathrm{m}$ particles show higher removal torque compared to a machined implant surface after 12 weeks of healing in either rabbit tibia or femur (Wennerberg et al., 1995). 

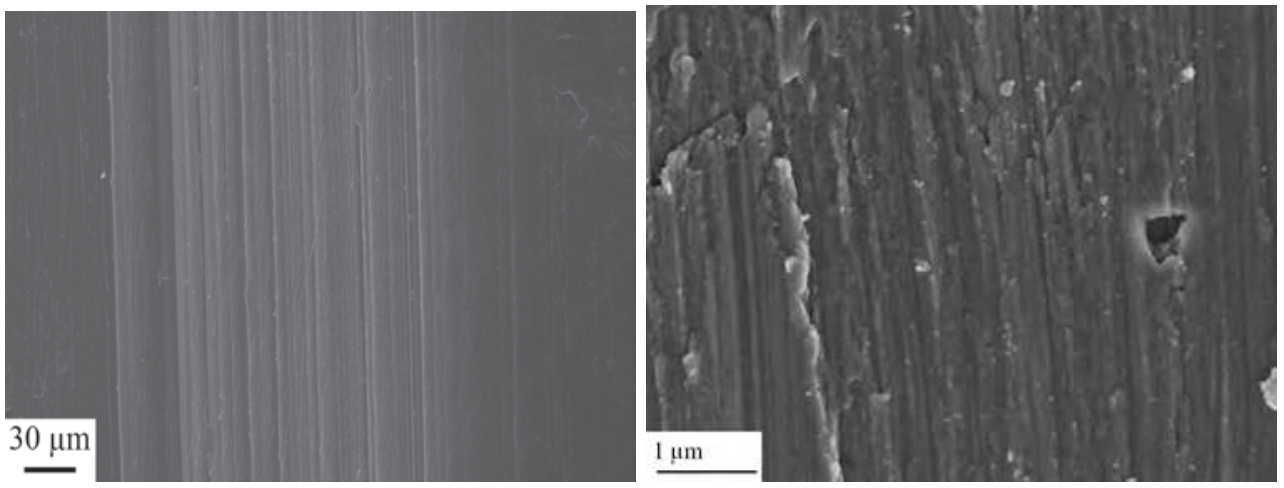

Fig. 1. Scanning electron micrograph of machined implant surface.

Significantly higher bone-implant contact was observed for the $25 \mu \mathrm{m}$ blasted surface compared to machined surface while the bone area within the threads were significantly higher for the machined surface after 12 weeks (Wennerberg et al., 1995) and 1 year healing (Wennerberg et al., 1997). The blasting particle material, either $\mathrm{TiO}_{2}$ or $\mathrm{Al}_{2} \mathrm{O}_{3}$ with a size of $25 \mu \mathrm{m}$, didn't show any difference in bone response with respect to removal torque, boneimplant contact and bone area after 12 weeks healing (Wennerberg et al., 1996a). Similar removal torque while significantly higher bone-implant contact and bone area was observed for implants blasted with $25 \mu \mathrm{m}$ particles compared to $250 \mu \mathrm{m}$ particles (Wennerberg et al., 1996b). The biological response to blasted implants show a optimal bone response with regards to removal torque values and bone implant contact to implants when a roughness of $1.5 \mu \mathrm{m}$ is a achieved (Wennerberg, 1996). No ultrastructural studies of the interface between bone and implant surface have been found in the literature for blasted implants.
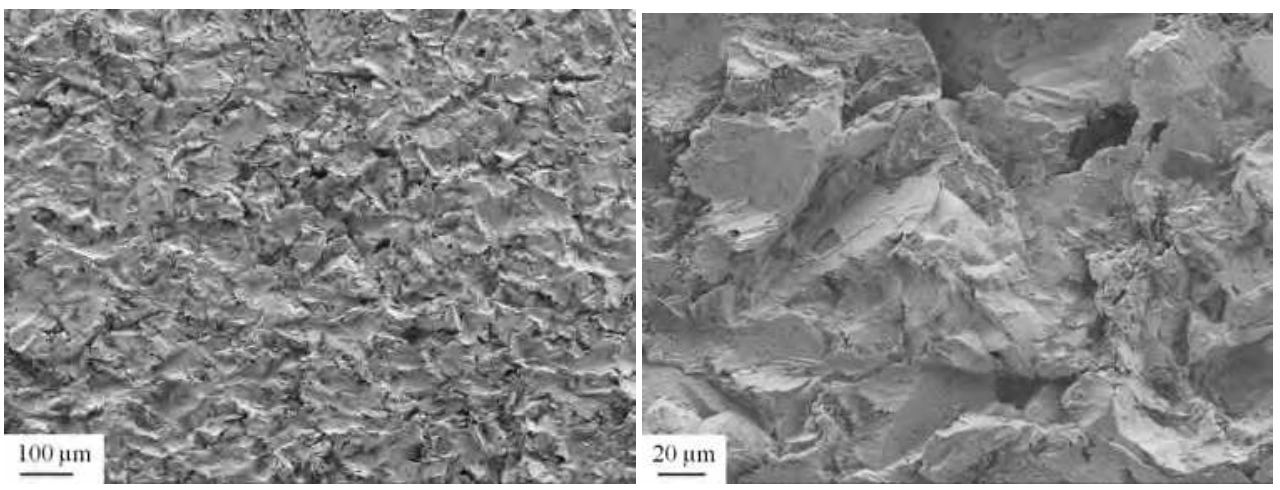

Fig. 2. Scanning electron micrograph of sandblasted surface.

\subsection{Acid etched surface}

With acid etching the surface is pitted by removal of grains and grain boundaries of the implant surface, as certain phases and impurities are more sensitive to the etching a selective removal of material is obtained (Figure 3). The resulting roughness is dependent on the bulk material, the surface microstructure, the acid and the soaking time. The surfaces are 
generally considered minimally rough as the typical $S_{a}$ values are $0.3-1.0 \mu \mathrm{m}$. Few analyses of the surface layer have been found, but speculative a titanium hydride layer could form due to the presence of hydrogen ions in the acid. The surface oxide has been found to be a native amorphous titanium oxide with a thickness of around $10 \mathrm{~nm}$ (Sul et al., 2006). The dental implant with acid etching presented implant surface morphology similar to Master Plus R (Conexão Sistemas e Protese) and Frialit Plus R (Maillefer, Swaziland).

The bone response to acid etched implants has been compared to machined implants in animal models. Significantly higher bone-implant contact was observed for acid etched implants compared to machined implants in a rabbit model after 1 and 2 months, while no difference was found after 14 days (Celletti et al., 2006). Also significantly higher boneimplant contact was observed in a poor bone quality dog model after 4 months healing while no difference in bone area was obtained (Weng et al., 2003). Significantly increased removal torque was needed to remove acid etched implants compared to the machined implant after 1, 2 and 3 months healing in rabbit while significantly lower removal torque was needed when comparing to titanium plasma sprayed implants (Klokkevold et al., 2001). Significantly lower bone-implant contact, bone area and removal torque was observed when comparing acid etched implants to anodic oxidized implants in rabbit tibia after 6 weeks healing (Gottlow et al., 2000).

On the ultrastructural level a number of publications have utilized the fracture technique for sample preparation. The interfacial bone tissue was composed of an electron dense zone (20-50 $\mathrm{nm}$ ) closest to where the implant had been in the section followed by either mineralized bone tissue or an intermediate layer of finely fibrilar mineralized zone $(100 \mathrm{~nm})$ which was found at areas with ongoing bone remodeling (Steflik et al., 1992, 1997, 1998). It was further found that osteocyte cellular processors was extending towards the implant surface (Steflik et al., 1994).
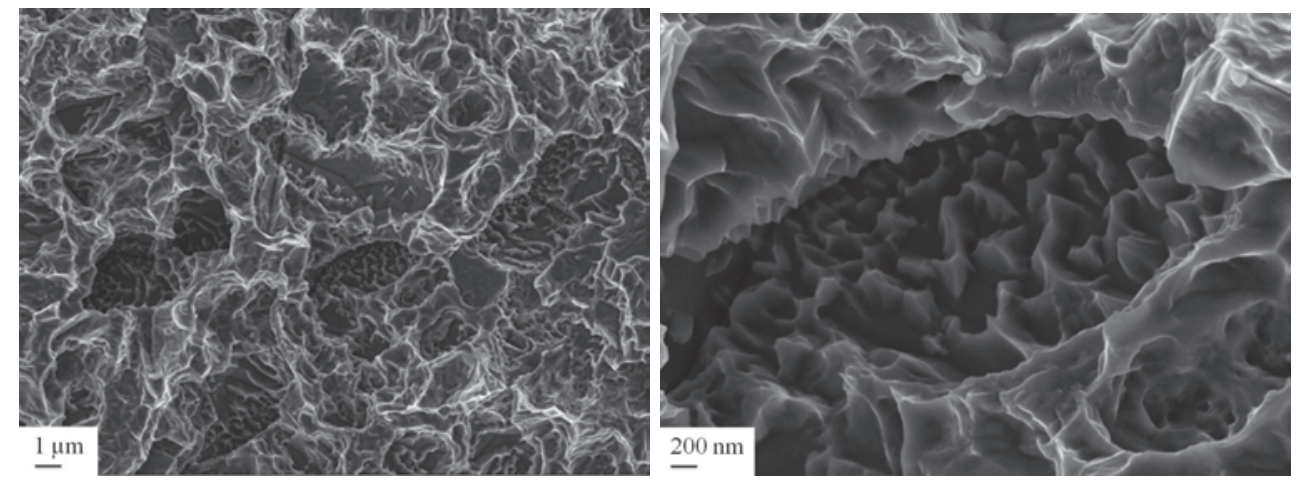

Fig. 3. Scanning electron micrograph of acid etched titanium surface.

\subsection{Sandblasted and acid etched surface (SLA)}

Commercially available dental implants are usually both blasted by particles and then subsequent etched by acids. This is performed to obtain a dual surface roughness as well as removal of embedded blasting particles. The etching reduces the highest peaks while smaller pits will be created and the average surface roughness will be reduced.

By the beginning of the 90s, intensive research had already shown that the sandblasted and acid etched surface had advantages compared to nearly every other type of implant surface, 
including the titanium plasma spray surface which, until that time, had been the standard for ITI implants (Buser et al., 1991, Schroeder et al. 1981).

Typical $S_{a}$ values for blasted and acid etched implants are 1-2 $\mu \mathrm{m}$. The chemical process of the acid etching will change the surface structure and it has been reported a creation of a titanium hydride layer with a thickness of 1-2 $\mu \mathrm{m}$ intermediate the surface oxide and the bulk metal (Conforto et al., 2004). Further, by rinsing the SLA implant in a nitrogen atmosphere and storing in saline solution until installation, the amount of carbon contamination could be reduced and improving the hydrophilicity of the implant surface (Rupp et al., 2006). The result of this procedure is creating a new hydrophilic surface (SLActive) (Figure 4). This procedure allows the SLActive to maintain a chemically active surface that conditioned to the human body.

Also the anions from the acid could be incorporated in the oxide layer such as fluoride ions if etched in hydrofluoric acid (Figure 5) (Cooper et al., 2006).

The bone response to blasted and etched implants has been compared to different implant surfaces. Higher removal torque was needed to unscrew the dual modified surface compared to solely acid etched implants in a pig model with 10 weeks of healing (SzmuklerMoncler et al., 2004).Significantly higher removal torque was obtained compared to machined surface while similar values compared to titanium plasma sprayed implants while no differences was observed in the bone density around the 3 different implant types (Buser et al., 1999). Significantly higher removal torque and higher bone-implant contact has been observed for blasted and fluoride modified implants compared solely blasted implants in a rabbit model after 1 and 3 months healing (Ellingsen et al., 2004).

Several studies have shown that SLActive implants achieve a higher bone contact and stability at earlier time points (6 weeks) when compared with SLA implants, and dramatically reduced healing times from 12 to 6 weeks (Buser et al., 2004; Schwarz et al., 2007). No ultrastructural studies of the interface to sandblasted and acid etched implant have been found in the literature.

\subsection{Anodized surface}

The anodized surface (TiUnite) is a partial crystalline and phosphate enriched titanium oxide characterized by a microstructured surface with open pores in the low micrometer range (Figure 6). Anodization or anodic oxidization as it's also called is an electrochemical process carried out in an electrolyte. The structural and chemical properties could be tailored by varying different process parameters, such as anode potential, electrolyte composition, temperature and current (Lausmaa, 2001). Further, depending on the electrolyte composition, different ions could be integrated in the oxide layer, such as phosphorous (Hall \& Lausmaa, 2000), calcium (Frojd et al., 2008) and magnesium (Sul et al., 2005). At lower voltages, below the dielectric breakdown limit, a rather constant oxide growth is obtained, while at higher voltages, an increased gas evolution is obtained rendering the surface oxide porous (Lausmaa, 2001). The crystalline structures of anodized oxides are amorphous with crystalline grains of anatase (Jarmar et al., 2008).

The bone response to anodized implants has been evaluated in different species and healing times and most often compared to the original machined surface. Significant higher bone to implant contact has been reported as well as increased biomechanical removal torque values for phosphorous containing anodized surfaces compared to machined surfaces in dog and rabbit (Albrektsson et al., 2000; Henry et al., 2000). The phosphorous containing anodized 

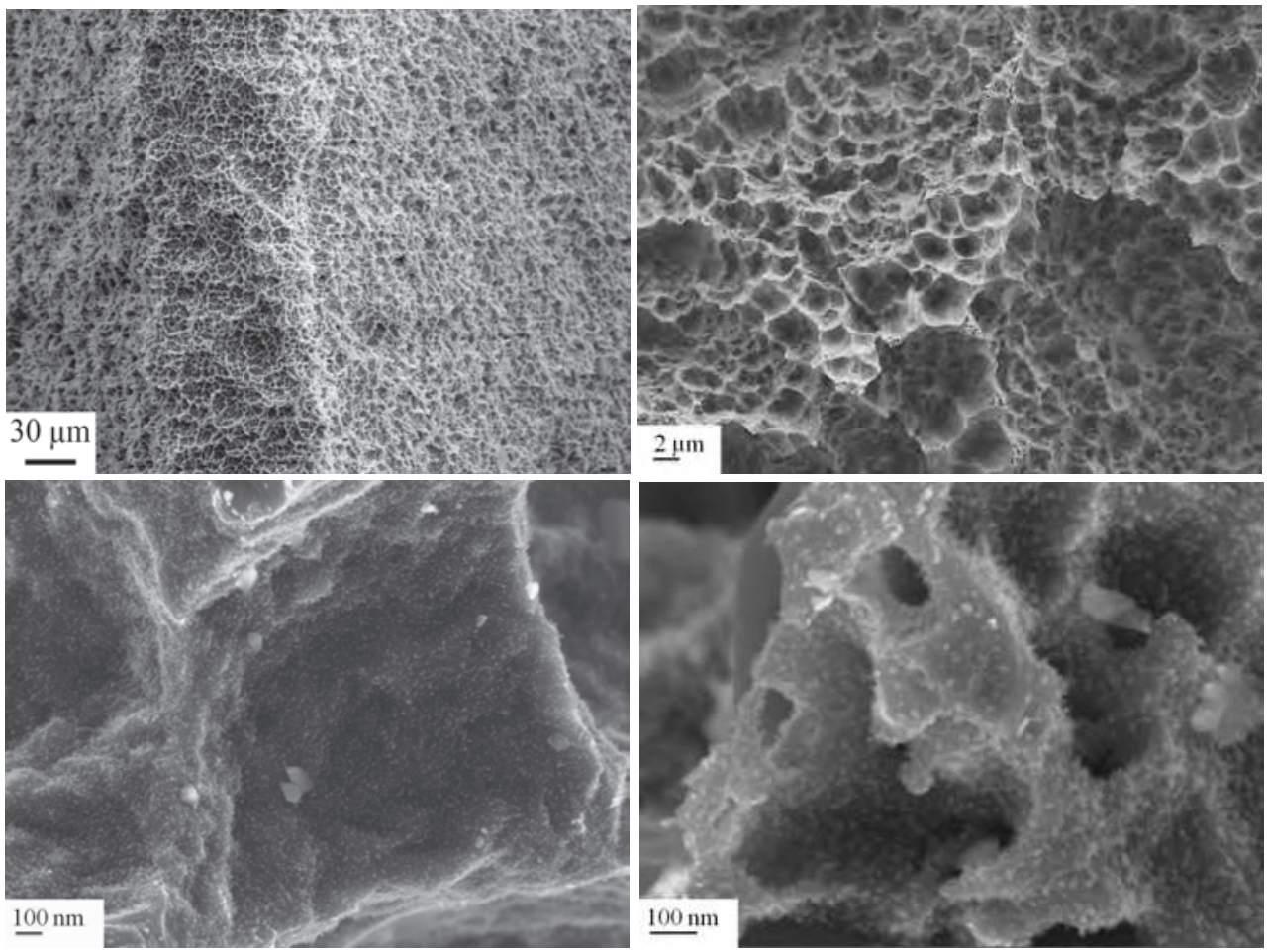

Fig. 4. Scanning electron micrograph of Straumann ${ }^{\circledR}$ Sandblasted and acid etched implant surface (SLA). Nanofeatures on the SLActive implant surface.
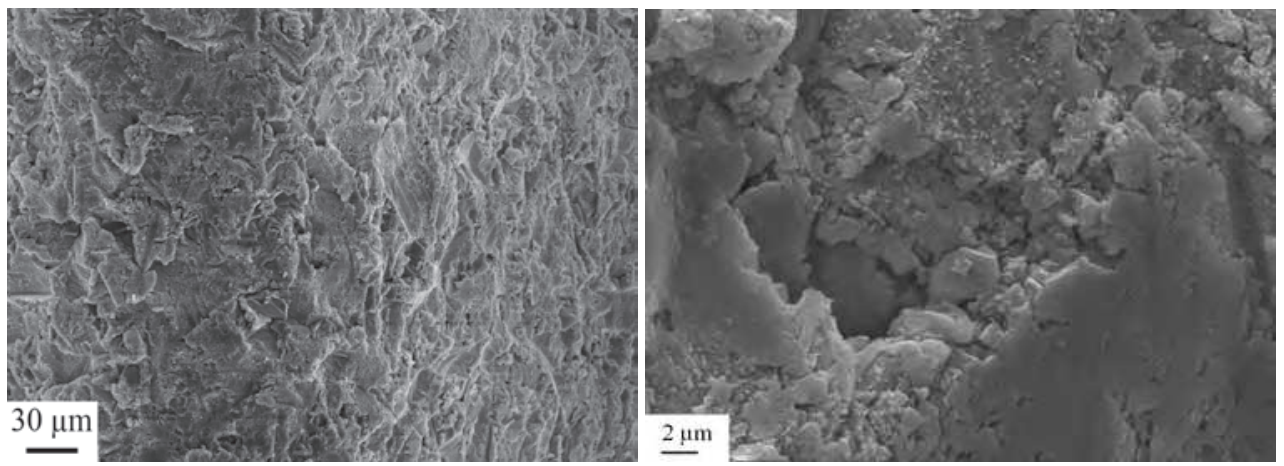

Fig. 5. Scanning electron micrograph of titanium dental implants in a fluoride modified surface (osseospeed ${ }^{\circledR}$ implant).

surface has also been shown to promote the early molecular events taking place at the immediate implant surface (Omar et al., 2010). Further, increased bone implant contact was obtained when calcium ions were incorporated in the anodized oxide compared to non 
calcium containing anodized oxide surface in the rabbit (Frojd et al., 2008) as well as higher removal torques were observed for magnesium incorporated oxides compared to non magnesium oxide surfaces (Sul et al., 2005a). One study have been performed on the ultrastructural level of oxidized implants, where a failed TiUnite (NobelBiocare) implant was removed prior to stage 2 surgery due to lack of osseointegration. TEM analysis of FIB prepared samples showed an amorphous zone between the bone tissue and the implant surface (Giannuzzi et al., 2007). Furthermore, in the later study, interdiffusion of titanium, phosphorus and calcium between the bone and the coating where intimate bone-implant contact was observed, suggested that chemical bonding also exists within this interface. The remove torque to anodized implants has been compared to sandblasted, acid etched, and machined implants in animal models. Significantly higher removal torque was observed for anodized implants compared other groups in a rabbit model after 12 weeks (Elias et al., 2008).

A higher clinical success rate was observed for the anodized titanium implants in comparison with turned titanium surfaces of similar shapes (Jungner et al., 2005). Two mechanisms have been proposed to explain this osseointegration: mechanical interlocking through bone growth in pores, and biochemical bonding (Schupbach et al., 2005; Sul et al., 2005b).
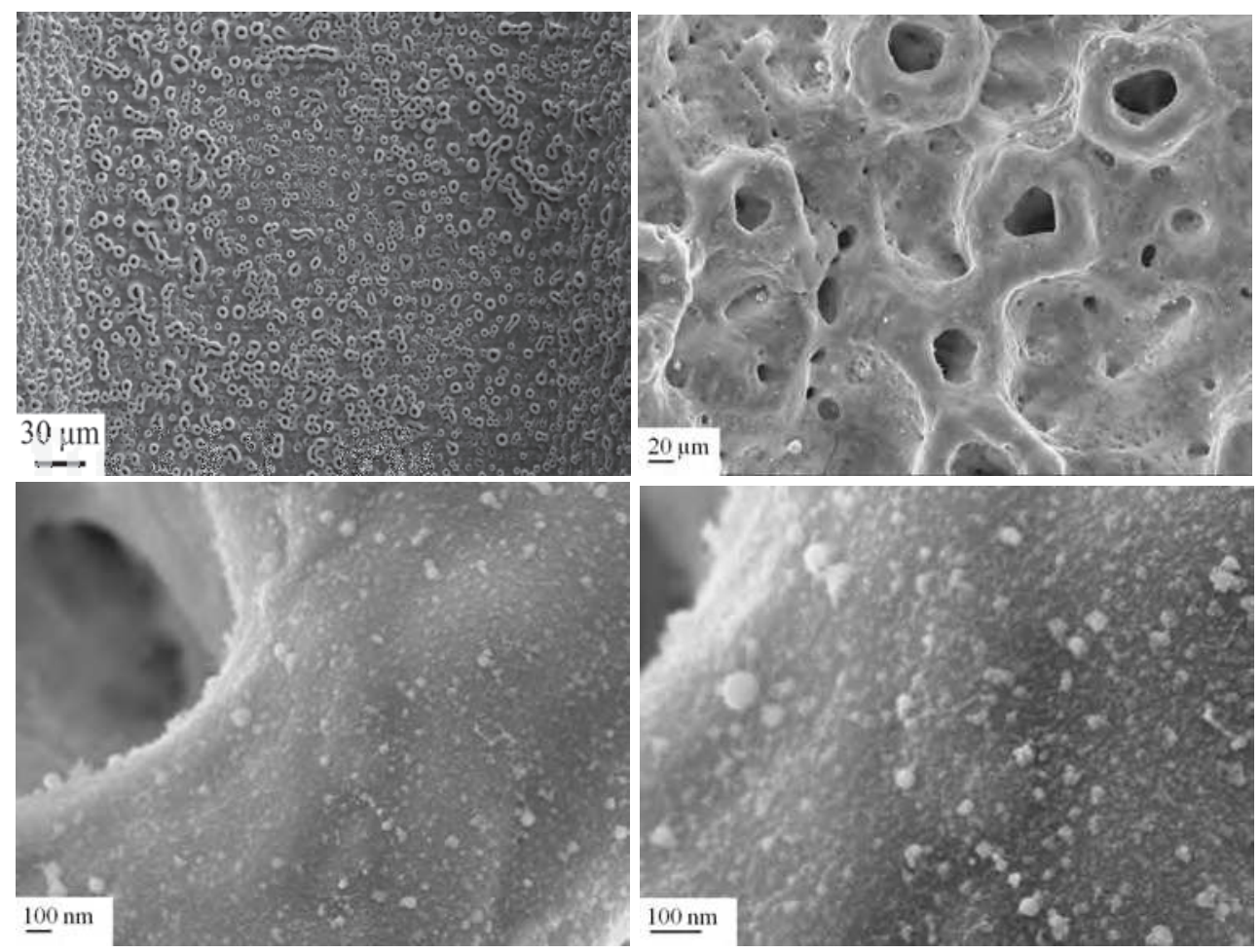

Fig. 6. A) Scanning electron micrograph of an anodized TiUnite ${ }^{\circledR}$ implant surface, B, C) the presence of pores with dimensions around 1-10 $\mu \mathrm{m}$, and smaller pores with diameters below $1 \mu \mathrm{m}, \mathrm{D})$ nanofeatures on the anodized implant surface. 


\subsection{Laser modified micro- and nano-structured surface}

Laser is an emerging field for use as a micromachining tool to produce a 3-D structure at micrometer and nanometer level. The technique is a method of choice for complex surface geometries. The technique generates short pulses of light of single wavelength, providing energy focused on one spot. It is rapid, extremely clean, and suitable for the selective modification of surfaces and allows the generation of complex microstructures/ features with high resolution. These advantages make the technique interesting for geometrically complex biomedical implants.

The Brånemark BioHelix Implant (Figure 7) has surface modified with laser micromachining process to create micro- and nano-structured surface roughness in only the inner part of the thread. The inner part of the thread is believed to be more suitable for bone formation than the outer part (Thomsson \& Esposito, 2008).

The laser technique has several advantages, add no chemicals and can be used in routine manufacturing. Only the valley and parts of the flank of the implant threads was laser treated while the remaining part was left as-machined. The idea behind this design is that the flack portion of the implant thread, which might have the higher risk to expose to the

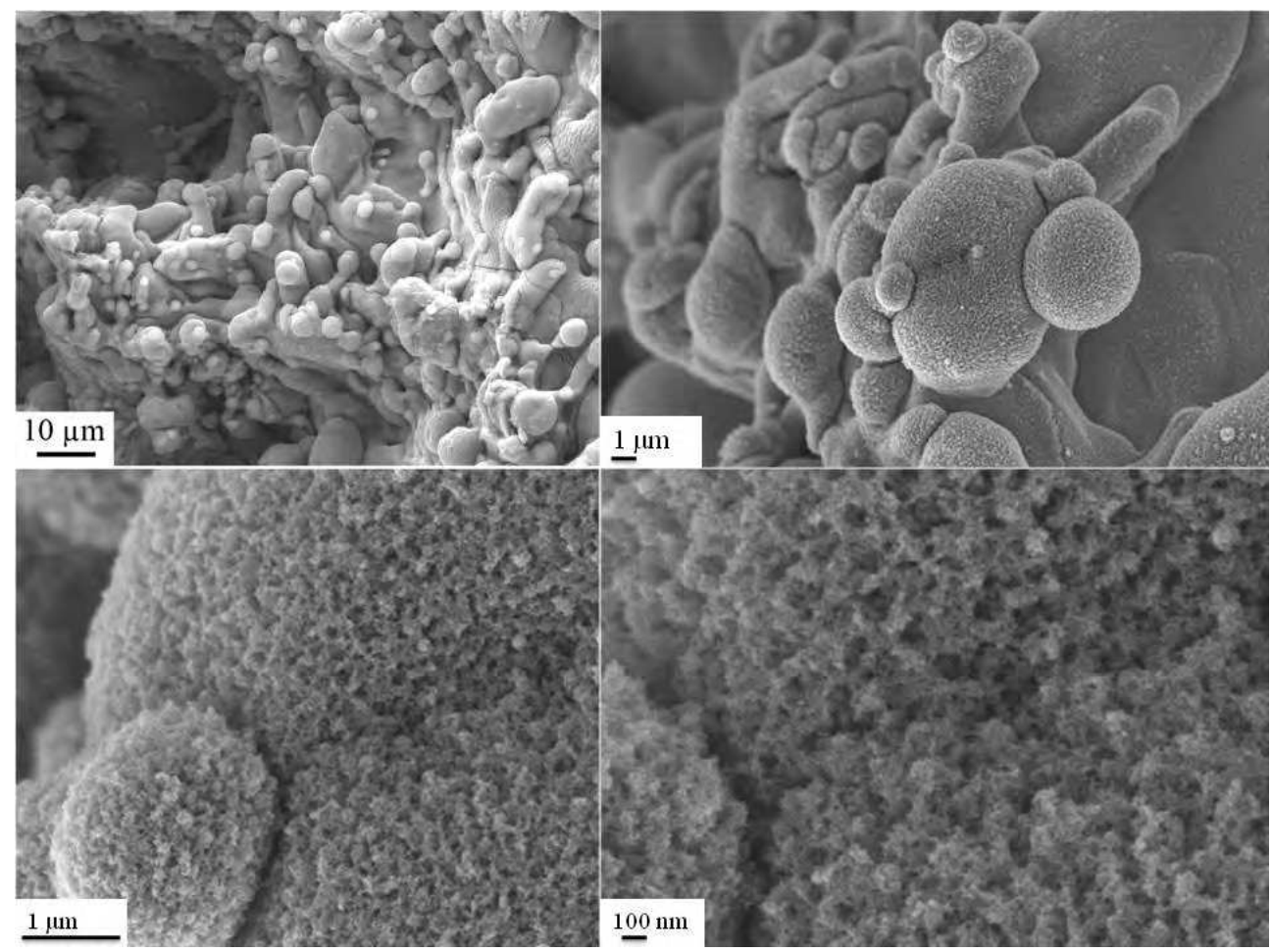

Fig. 7. Scanning electron micrograph of Brånemark BioHelix implant. The bottom portion of the threads is modified by laser processing, whereas the parts of the flanks and the tops are as machined. Higher magnification of the laser modified surface, showing the nanotopography. 
microorganism and plaque, is characterised by relatively smooth surface to minimize the incidence of peri-implantitis, whereas the valley part of the implant threads has the rougher surface.

Short-term, experimental in vivo studies of laser-modified titanium implants with nanoscale surface topographical features have demonstrated a significant increase in removal torque and different fracture mechanisms (Palmquist et al., 2010; Brånemark et al., 2010). Of clinical importance is that nanostructured surfaces promoted long-term bone bonding and interface strength in vivo as determined by a coalescence between mineralized bone and the nanostructured surface and a substantial increase in removal torque (Palmquist et al., 2010).

One 1-year retrospective case series showed excellent clinical results of Brånemark BioHelix dental implants placed according to conventional procedures (Thomsson \& Esposito, 2008). However, randomized clinical trials with suitable controls are needed to confirm these preliminary results.

\section{Calcium phosphate coatings on titanium implants}

Some surface reactive materials have shown the ability to form an interfacial chemical bond with surrounding tissues through a series of biophysical and biochemical reactions, causing 'bioactive fixation' of the implant (Cao \& Hench 1996). Bioactive materials can be biostable (i.e. synthetic hydroxyapatite) or bioresorbable (i.e. bioactive glasses and glass-ceramics). Some bioactive ceramics like bioactive glasses of certain compositions have been claimed to have a real chemical bonding ability with soft tissues (Wilson et al., 1981). However, bioactive ceramics in the bulk form are not suitable for load-bearing applications as their flexural strength, strain-to-failure and fracture toughness are less than that of bone and their elastic moduli are greater than that of bone. For these reasons they are usually applied as coatings on metallic implants that possess superior mechanical properties. Calcium phosphates $(\mathrm{CaP})$ are the most common family of bioceramics well-known for their use in biological application. $\mathrm{CaP}$ in the crystallographic form of apatite is an important mineral constituent of bone. Calcium phosphate ceramics are integrated within bone following a well known sequence of events (Frayssinet, et al. 1993). They are considered to be bioactive and osteoconductive. Bioactivity would be due to epitaxial nucleation of carbonated apatite crystals at the surface of ceramic grains. This layer of biological apatite might contain endogenous proteins and might serve as a matrix for osteogenic cell attachment and growth (Davies 2003).

Different types of methods have been introduced to prepare calcium phosphate coatings on dental implant (table 1 \& 2). These methods can be divided to two groups: physical and chemical methods. Sometimes they can also be called dry and wet methods. Typically physical techniques include plasma spraying deposition, physical vapour deposition, magnetron sputtering deposition, ion beam assisted deposition, pulsed laser deposition, and hot isostatic pressing. Chemical techniques include sol-gel method, biomimetic process, electrochemical deposition, micro-arc oxidation (MAO) and electrophoretic deposition.

Physical techniques are widely used for preparation of calcium phosphate coatings. The bonding strength between coatings and implants is higher than those prepared by chemical methods. However, most of these methods have difficulties in coating of complex 3D 
geometries such as rough screw-shaped dental implants. Chemical methods can be used to treat the implants with complex geometries. The treating temperature of chemical methods is low. The most important thing is that bioactive molecules and drugs can be incorporate into calcium phosphate coatings via chemical methods, such as biomimetic process.

\begin{tabular}{|c|c|c|}
\hline Technique & Characteristics & Properties \\
\hline $\begin{array}{l}\text { Plasma spraying } \\
\text { deposition (PS) }\end{array}$ & $\begin{array}{l}\text { (1). High temperature } \\
>1000^{\circ} \mathrm{C} \\
\text { (2). Reproducible } \\
\text { (3). High deposition rate } \\
\text { (4). Atmosphere: Air, vacuum } \\
\text { (popular), low pressure }\end{array}$ & $\begin{array}{l}\text { (1). } 2 \mathrm{D} \\
\text { (2). No homogeneity of } \\
\text { crystallnity } \\
\text { (3). Promote fast and strong } \\
\text { fixation and bone growth in } \\
\text { vivo and clinically } \\
\text { (4). Bacteria adhesion }\end{array}$ \\
\hline $\begin{array}{l}\text { Magnetron sputtering } \\
\text { deposition (MS) }\end{array}$ & $\begin{array}{l}\text { (1). High deposition rate } \\
\text { (2). Metallic and non-metallic } \\
\text { substrates }\end{array}$ & $\begin{array}{l}\text { (1). } 2 \mathrm{D} \\
\text { (2). Ion doped hydroxyapatite } \\
\text { and composites coatings }\end{array}$ \\
\hline
\end{tabular}

\begin{tabular}{|c|c|c|}
\hline $\begin{array}{l}\text { Ion beam assisted } \\
\text { deposition (IBAD) }\end{array}$ & $\begin{array}{l}\text { (1). The coating is amorphous, } \\
\text { and needed to be heat treated } \\
\text { further } \\
\text { (2) The final crystallinity is } \\
\text { dependent on the time, } \\
\text { temperature and amount of } \\
\text { water vapour present during } \\
\text { the coating. } \\
\text { (3). Low deposition rate } \\
\text { compared to PS }\end{array}$ & $\begin{array}{l}\text { (1). } 2 \mathrm{D} \\
\text { (2). High adhesive strength } \\
\text { (3). Graded crystallinity }\end{array}$ \\
\hline $\begin{array}{l}\text { pulsed laser } \\
\text { deposition (PLD) }\end{array}$ & $\begin{array}{l}\text { (1). Fast deposition rate } \\
\text { (2).Multi-component and } \\
\text { metastable materials }\end{array}$ & $\begin{array}{l}\text { (1). } 2 \mathrm{D} \\
\text { (2) HA, OCP , a, } \beta \text {-TCP }\end{array}$ \\
\hline $\begin{array}{l}\text { Hot isostatic pressing } \\
(\mathrm{HIP})\end{array}$ & $\begin{array}{l}\text { (1). High temperature and } \\
\text { pressure }\end{array}$ & (1). $2 \mathrm{D}$ \\
\hline
\end{tabular}

Table 1. Physical techniques for implant coatings

In the last four decades, continuous research on HA and CaP have not only focused on tissue-coating interface, but also on the problems associated with the coating process and optimization of coating properties for maximum tissue response (Sun et al., 2001). A major dilemma for evaluation the bone tissue response of $\mathrm{CaP}$ coating compare to uncoated titanium implants (Morris et al. 2000; Barrere et al. 2003), is that the process of surface chemical modifications are often associated changes in topography and visa-versa. In addition, several factors may have influenced the results of in vivo evaluation at the interface of $\mathrm{CaP}$ coated implants. 


\begin{tabular}{|c|c|c|}
\hline Technique & Characteristics & Properties \\
\hline Sol-gel method & $\begin{array}{l}\text { (1). Combine with } \\
\text { different coating process, } \\
\text { such as dip and spinning } \\
\text { coatings, following } \\
\text { sintering } \\
\text { (2).Substrates with } \\
\text { complex geometry } \\
\text { (3).Metallic and non- } \\
\text { metallic substrates } \\
\text { (4). Thin film }\end{array}$ & $\begin{array}{l}\text { (1). 3D } \\
\text { (2). Easy to control the } \\
\text { composition } \\
\text { (3). High sintering } \\
\text { temperature for HA coatings }\end{array}$ \\
\hline Biomimetic process & $\begin{array}{l}\text { (1). Low temperature } \\
\text { (2). Different types of } \\
\text { substrates which could } \\
\text { induce HA formation, } \\
\text { such as metallic implants, } \\
\text { bioceramics, polymers }\end{array}$ & $\begin{array}{l}\text { (1). 3D } \\
\text { (2). Bone-like crystal } \\
\text { structure } \\
\text { (3). Ion doped HA } \\
\text { (4). Low bonding strength } \\
\text { (5) Porous structure } \\
\text { (6). Incorporate bio- } \\
\text { molecules and drugs }\end{array}$ \\
\hline Electrochemical deposition & $\begin{array}{l}\text { (1). Conducting substrates } \\
\text { (2). Chargeable particles } \\
\text { (3). Low temperature }\end{array}$ & $\begin{array}{l}\text { (1).3D } \\
\text { (2). Low boding strength } \\
\text { between coatings and } \\
\text { substrates } \\
\text { (3). Composite coatings } \\
\text { (4). (4). Thick and cracked } \\
\text { coatings }\end{array}$ \\
\hline Electrophoretic deposition & $\begin{array}{l}\text { (1). Conducting substrates } \\
\text { (2). Chargeable particles } \\
\text { (3). Low temperature }\end{array}$ & $\begin{array}{l}\text { (1). 3D } \\
\text { (2). Low boding strength } \\
\text { between coatings and } \\
\text { substrates } \\
\text { (3). Composite coatings } \\
\text { (4). Thick and cracked } \\
\text { coatings }\end{array}$ \\
\hline Micro-arc oxidation (MAO) & $\begin{array}{l}\text { (1). Ambient temperature } \\
\text { (2). Substrates with } \\
\text { complex geometry } \\
\text { (3). Electrolytic oxidation }\end{array}$ & $\begin{array}{l}\text { (1).3D } \\
\text { (2). HA and ion doped HA }\end{array}$ \\
\hline Ultrasonic spray pyrolysis & $\begin{array}{l}\text { (1). Ambient temperature } \\
\text { (2). Continuous and pulse } \\
\text { spray }\end{array}$ & $\begin{array}{l}\text { (1). } 2 \mathrm{D} \\
\text { (2). Cracks in coatings } \\
\text { (3). The bonding strength of } \\
\text { coatings prepared by pulse } \\
\text { spray is better than that by } \\
\text { continuous spray }\end{array}$ \\
\hline
\end{tabular}

Table 2. Chemical techniques for implant coatings. 


\subsection{Plasma spraying}

HA coatings were first introduced in the middle 1980s for improved fixation between bone and implant (Furlong and Osborn, 1991). Since that time, these materials have been extensively used in orthopaedic and dental implants. Plasma-spraying is commercially the most frequently used method for deposition of calcium phosphate coatings, such as HA, onto implant materials to improve their bioactivity.

The thickness of hydroxyapatite coatings produced by plasma-spray varies from 100 to 300 $\mu \mathrm{m}$ (Willmann, 1997). With plasma spraying processing the surface area of titanium implant has increased up to approximately six times than the original surface. The arithmetic average roughness $\left(R_{a}\right)$ for hydroxyapatite coated by plasma-spraying process is $5.0 \pm 1.0$ $\mu \mathrm{m}$.

The bone tissue responses to plasma sprayed hydroxylapatite (HA) coatings on titanium implant have been well documented. Several earlier experimental studies have shown a higher percentage of bone-implant contact for HA-coated implants when compared with titanium implants in different species and types of bone (De Groot et al., 1987; Denissen et al., 1990). The histological findings demonstrated that the cortical bone reaction to titanium and HA-coated titanium was similar, but the HA-coated surfaces induced more bone deposition in areas on non-cortical bone contact than uncoated surfaces. Based on findings of a substantial reduction of the HA coating thickness after 12 weeks (Jansen, et al., 1991). Other studies in animal model have shown that the chemical composition of HA coating has a positive influence on the bone response, while, the influence of roughness is less evident (Vercaigne, et al., 1998).

In reference to the interfacial strength, the HA-coated implants were reported to have higher push-out strength in compared to non-coated implants (Cook et al., 1987). HA coated implants have also exhibited a greater torque removal value compare to Ti screw implants (Carr et al., 1995).

On the ultrastructural level, newly formed acicular crystallites were adjacent to the larger HA crystals of the plasma-sprayed coating. Needle-like crystals seemed even to grow at the surface and in the smallest holes of the HA coating. Collagen fibrils were not observed in the bonding area. The tiny crystals of the newly formed mineralized tissue developing in the cavities of the implanted material appeared to be more or less randomly oriented, thus resembling woven bone (Hemmerle, et al. 1997).

However, despite clinical success, it has been recognized that the plasma-spraying method has several disadvantages, including poor long-term adherence of the coating to the substrate material, non-uniformity in thickness of the deposited layer, and variations in crystallinity and composition of the coating. Other significant factors causing implant failures include microbial infection (Rosenberg et al., 1991; Verheyen et al., 1993).

\subsection{Sputter-deposition}

Sputtering process has been shown to be a particularly useful technique for the deposition of bioceramic thin films (based on Ca-P systems), due to the ability of the technique to provide greater control of the coating's properties and improved adhesion between the substrate and the coating.

Scanning electron microscopy showed that the deposited films had a uniform and dense structure (Figure 8). The calcium phosphate has been reported to range from 1.5 and 2.6. The in vitro dissolution appeared to be determined by the degree of the coating's crystallinity 
(Ong \& Lucas, 1998; Ong et al, 1997). The disadvantages with sputter coating is extensive time consuming, produces amorphous coatings and $\mathrm{Ca} / \mathrm{P}$ ration of the coating is higher than of synthetic HA.

The thickness of hydroxyapatite coatings produced by sputter process varies from 0.5 to 3.0 $\mu \mathrm{m}$ (Ding, 2003). With sputter processing the surface roughness of the coating depends on the roughness of the substrate (Hayakawa et al., 2000). The arithmetic average roughness $\left(\mathrm{R}_{\mathrm{a}}\right)$ for hydroxyapatite coated by sputter process is $3.0 \pm 1.2 \mu \mathrm{m}$.

In a study using $\mathrm{TiO} 2$-gritblasted and sputtered $\mathrm{CaP}$ implants, the sputtered $\mathrm{CaP}$ coatings showed improved initial fixation and healing response when implanted into the trabecular bone of the goat (Vercaigne et al., 2000; Hayakawa et al., 2000). In a separate study comparing sputtered $\mathrm{CaP}$ coatings to plasma-sprayed HA coatings, the ultimate interfacial strength observed for the sputtered CaP-coated implants (as-sputtered and sputtered followed by post- deposition heat treatment) was not significantly different from the plasma-sprayed HA coated implants 12 weeks after implantation, suggesting that sputtered $\mathrm{CaP}$ coatings are comparable to plasma-sprayed HA coatings with respect to ultimate interfacial strength. This was supported by the histological findings that indicated no statistical difference in percent bone contact length between plasma-sprayed HA-coated implants and the as-sputtered CaP-coated implants at 12 weeks after implant placement (Yang et al., 2005).

Further, sputtered calcium phosphate coated titanium implants have showed higher removal torque compared to control uncoated titanium implants after 3 weeks of healing. This difference in the removal torque strength was no longer evident after 12 weeks of healing (Ong et al., 2002).
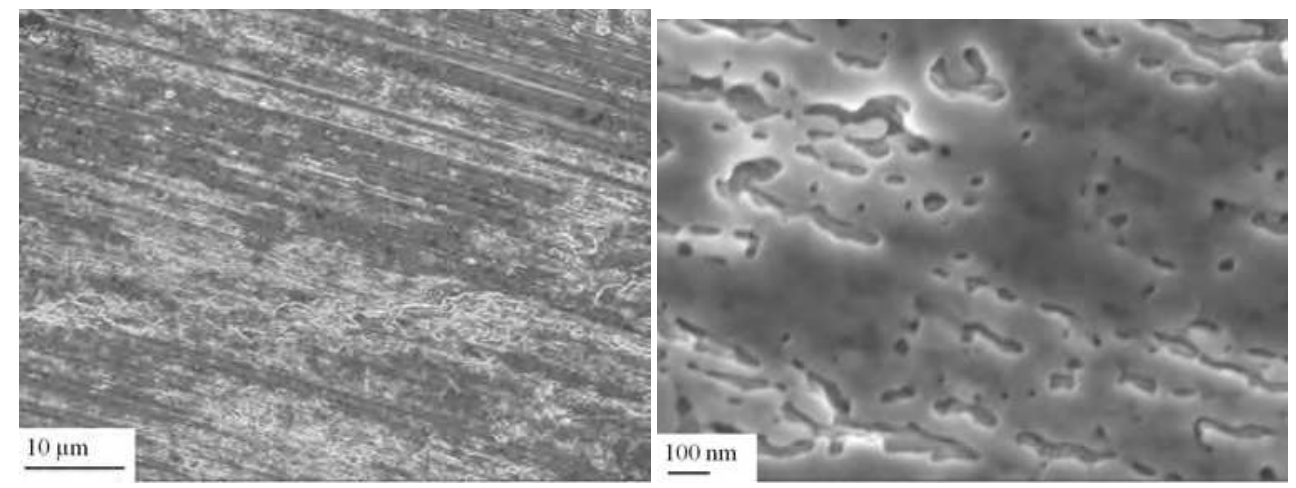

Fig. 8. Scanning electron micrograph of sputter $\mathrm{CaP}$ coated titanium implant.

\subsection{Biomimetic precipitation}

Biomimetic deposition of calcium phosphate onto surfaces of implant materials is a technique originally developed by Kokubo and co-workers (Kokubo et al, 1990). This method allows hydroxyapatite and other calcium phosphate surfaces to be deposited on substrates in a simulated body fluid (SBF) under physiological conditions of temperature and $\mathrm{pH}$, on complex geometrical shapes.

The classical biomimetic Ca-P coating normally requires an immersion period of about 1428 days with replenishment of SBF solution. It is observed that the thickness of the apatite 
layer increases as the immersion period increases. In very recent years efforts have been made (Habibovic et al., 2002; Ma et al., 2003; Barrere et al., 2004; Muller et al., 2004) to make this process fast to increase its practical utility.

In the biomimetic method, a layer of usually rough and porous, calcium-deficient apatite will grow on the surface of implants. The $\mathrm{Ca} / \mathrm{P}$ ratio for $\mathrm{HA}$ biomimetic coating was 1.51 (He et al, 2007), and the thickness of HA coatings produced by biomimetic process varies from 20 to $25 \mu \mathrm{m}$ (Yang et al., 2005).

It is well known that the tissue and cell response could be considerably influenced by the composition and topography of the implant surfaces. ${ }^{14}$ Biomimetically produced apatite surfaces may, therefore, be useful in facilitating early bone ingrowth into porous surfaces without the potential for coating debris, macrophage infiltration, fibrous tissue encapsulation, and eventual coating failure as may occur with the plasma-sprayed hydroxyapatite coating. ${ }^{15}$

Little information is available on bone tissue responses to biomimetic coatings on titanium implant. Very few experimental studies have shown the biomimetic HA coating did not have any positive effect on new bone formation and on the shear strength at the early bone healing stage (Fuming, et al, 2008; He et al, 2009; Yang, et al, 2009).

Recently, it has been found that the morphology of the biomimetic apatite surfaces changed by adding ions as substitutes to HA such as strontium (Sr), and silicate (Si) ions (Zhang \& Zou, 2009; Xia et al., 2010).

Adding Sr ion change the morphology of biomimetic apatite from plate-like for the pure HA to sphere-like (Figure 9). Surface analysis results showed that $10-33 \%$ of Ca ions in the apatite have been substituted by Sr ions, and that the Sr ions were chemically bonded with apatite and successfully incorporated into the structure of apatite (Xia et al., 2010).

Our recent findings have showed that biomimetically prepared Sr and Si-ion substituted apatite films deposited on Ti implants provide bioactive surfaces which promote early bone formation. The mechanisms behind these responses may be release of $\mathrm{Sr}$ ions, and the nature of bonding of $\mathrm{Si}$ ions in the HA structure, whose fast hydrolysis is deemed to contribute to the surface hydrophilicity, respectively (Ballo et al., 2010).

\subsection{Bioactive glass coatings}

Originally introduced by Hench (Hench et al., 1971), silica-based bioactive glasses are slowly resorbing synthetic osteoconductive materials which are able to form strong chemical bond with bone. Several methods have been applied to obtain a bioactive glass coating on the load bearing part of the implants (Hench \& Andersson, 1993). Several attempts have been made to create bioactive glass coatings on alumina (Greenspan \& Hench 1976), stainless steel (Schepers et al., 1989), Co-Cr-Mo alloy (Lacefield \& Hench, 1986), fiber-reinforced composite (Ballo et al. 2009, 2011), and titanium alloys (West et al., 1990, Kitsugi et al., 1996). Application of a double glass coating has been suggested to solve the problem of differences in thermal expansion coefficients. Recently, several attempts were made to prepare bioactive glass coatings on titanium and Ti6Al4V (Bloyer et al., 1999, Saiz et al., 2002). Application of a ground layer prepared from inert glass with a thermal expansion coefficient close to that of Ti6Al4V provided good adhesion to the substrate (Oku et al., 2001). This ground coating can be used in combination with more surface reactive glass coatings (Gomez-Vega et al., 2000a), with embedded hydroxyapatite and/or bioactive glass particles (Gomez-Vega et al., 2000b), or a sol-gel-derived silica coating (Gomez-Vega et al., 2001). Reactive plasma spraying 
(Schrooten et al., 2000) or processing with infra-red laser (Moritz et al., 2004) have also been attempted to create bioactive glass coatings on titanium and its alloys.
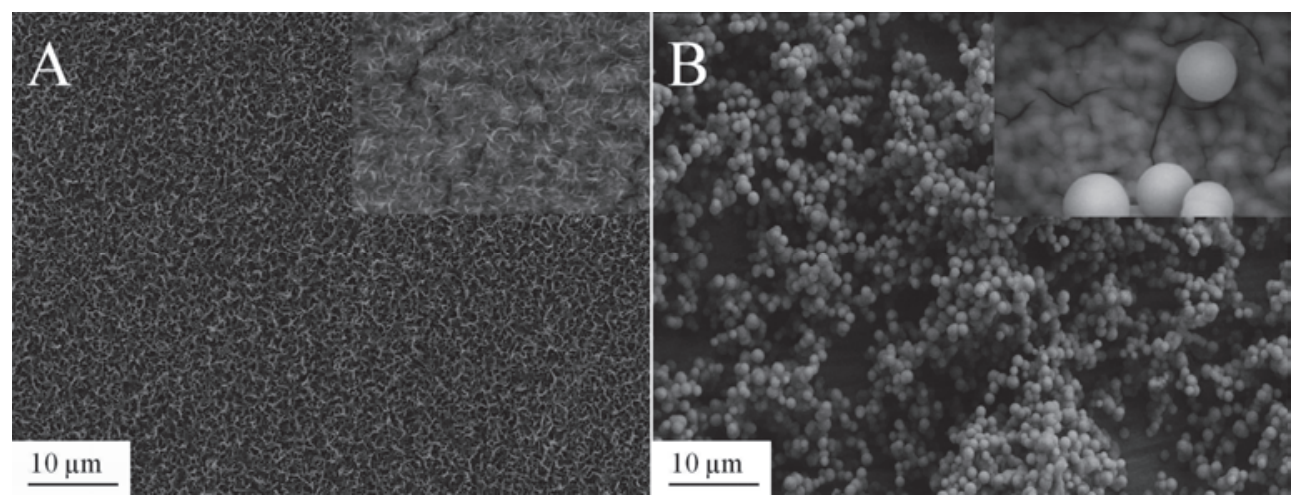

Fig. 9. Scanning electron micrograph of biomimetic apatite surface modification of titanium implants. A) Pure apatite with plate-like structure, B) Sr-HA with sphere-like structure.

Several experimental studies have shown that titanium implants coated with BAG were integrated into host bone without a connective tissue capsule and significantly greater osseointegration and high removal torque in compare to the control uncoated titanium implants (Moritz et al., 2004). Also significantly higher bone-implant contact was observed for BAG coated titanium implants than those in both the uncoated and HA coated titanium implants after 4, 12, and 24 weeks of healing (Xie et al., 2010).

Recently, one 1-year comparative clinical study showed that bioactive glass coated implants were as equally successful as hydroxyapatite in achieving osseointegration and supporting final restorations (Mistry et al., 2011). However, further clinical studies are needed to confirm these preliminary results.

\section{Biological response to titanium implant surface modification}

Osseointegration is the fortunate outcome of bone tissue healing around titanium implant. It is a biological process in which a direct anchorage is established by formation of bone tissue around the implant without the growth of fibrous tissue at the bone-implant interface (Branemark, Adell et al. 1969; Branemark, Hansson et al. 1977). Despite the wide use of osseointegrated titanium implants and the substantially growing research on the development of new titanium surfaces and/or modification of existing surfaces, a detailed understanding of the mechanisms of osseointegration is still lacking. The current knowledge on the process of healing at different titanium implants is predominantly gained from histological and biomechanical data and correlation with normal fracture healing. The histological and biomechanical studies strongly advocate that bone would respond differently by alteration of the implant surface properties (Larsson, Esposito et al. 2001).Consequently, great attention has been given to study, in vitro, the cellular and molecular activities on different substrates and to extrapolate the results to the actual interfacing between implant and living bone tissue. Based on results from the in vitro studies, the surface influences the initial sequences of protein adsorption, platelet adhesion and haemostasis, complement activation, inflammation and osteogenic cell response 
(Nygren, Tengvall et al. 1997; Park and Davies 2000; Masaki, Schneider et al. 2005; Tan, Qian et al. 2006). Taking into account the important information acquired from these studies, however, they remain to large extent unrepresentative for the actual paradigm of the in vivo implantation scenario. For instance, early in vivo studies revealed that that the process of bone formation at titanium implants is preceded by recruitment of cells of different types and at different levels of morphological differentiation (Sennerby, Thomsen et al. 1993; Sennerby, Thomsen et al. 1993). However, the functional activities of the different cells and the roles of cells other than osteogenic ones in the healing process have not been clearly defined. A key question is how early molecular and cellular events are influenced by material surface properties in vivo, and how these early events influence the organization of the surrounding tissue and its interlocking or bonding with the material surface and, in turn, the capacity of this interface to adapt to long-term continuous load interactions.

The new advances in research technologies have made it possible to apply molecular techniques to analyze the interface between the living tissues and implant surface. Such tools can be used at high degree of precision to discover mechanisms that govern osseointegration including events of early inflammation, mesenchymal stem cells (MSCs) recruitment and cell-cell communication. Nevertheless, the advent of these approaches requires establishing reliable procedures to collect cell samples from within the in vivo interface in the way that their spatial distribution can be determined. Using the highly sensitive quantitative polymerase chain reaction (qPCR) in conjunction with the well documented rat tibia model, it has been revealed that gene expression of the interfacial implant-adherent cells is immediately and differently influenced by titanium implants depending on their surface properties (Omar, Lenneras et al. 2010; Omar, Svensson et al. 2010). The model was further combined with immunohistochemistry and SEM to confirm the presence of specific cell types at the interface. Ultimately, the regulations of inflammation, bone formation and bone resorption processes were correlated to the strength of the early formed bone-implant interface, by measuring the removal torque (Omar, Lenneras et al. 2011) (Table 3).

The inevitable early inflammation and the processes of cellular recruitment and adhesion to titanium implants in bone are obscure and have not received similar attention as that given during soft tissue integration. In soft tissue healing around titanium discs, higher release of tumor necrosis factor-alpha (TNF-a) was observed in response to porous titanium with and without plasma protein layer compared to machined titanium after 3 hours (Jansson, Kalltorp et al. 2002), as well as for machined titanium compared to copper after 12 hours of implantation (Suska, Esposito et al. 2003). The soft tissue data presented strong evidence on the modulation of inflammatory cell responses by titanium surface roughness and composition, respectively. The local releases of inflammatory mediators, in addition to the modulatory role of the implant surface, initiate the cascade that controls early inflammatory events. These events involve the release and regulation of primary acute phase cytokines. By activation of their target cells, these cytokines generate a second wave of cytokines, including members of the chemokine family.

In bone, higher expression of the chemokine, monocyte chemoattractant protein-1 (MCP-1), was revealed at machined implant surface compared to anodically oxidized implant (Omar, Lenneras et al. 2010). This was coupled with higher expression of pro-inflammatory cytokines TNF- $\alpha$ ( 3 hours and 1 day after implantation) and interleukin-1beta (IL-1 $\beta$ ) (1 day and 6 days after implantation) at the machined implants (Omar, Lenneras et al. 2010; Omar, Svensson et al. 2010). The temporal expression profile for MCP-1 was similar to the 
expression of pro-inflammatory cytokines telling that the recruitment of inflammatory cells was accompanied by cytokine activity at both surfaces. The immunohistochemical sections for the same time period showed CD163-labeled monocytes/macrophages at both surfaces. However, a general SEM observation in all samples was that a large amount of fibrinous material covered the machined implants (Figure 10). Fibrin has been shown to enhance the pro-inflammatory response to biomaterials (Tang and Eaton 1993) which might explain the upregulated pro-inflammatory cytokine expression at the machined surface as early as 3 and 24 hours (Omar, Lenneras et al. 2010) and at later time periods (Omar, Svensson et al. 2010).
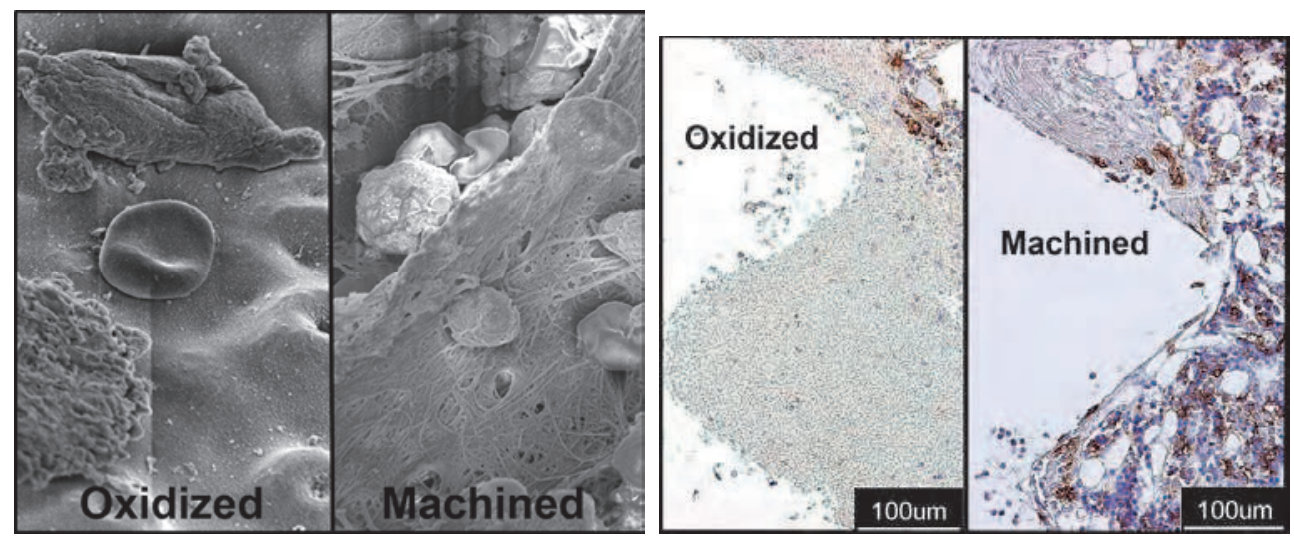

Fig. 10. Left, scanning electron microscopy images of oxidized and machined implant retrieved $24 \mathrm{~h}$ after implantation. Right, immunohistochemical sections of the interface $24 \mathrm{~h}$ after implantation showing CD163-positive monocytes/macrophages in the interface zone. Biological material adherent the machined implant was highly fibrinous with numerous erythrocytes and leukocytes compared to the oxidized implants.

One of the major observations during the initial 24 hours after implantation in bone was the significant modulation of the chemokine receptor CXCR4 (Omar, Lenneras et al. 2010). These results provided the first set of data on the role of this chemokine receptor at titanium implants in bone. After 12 hours of implantation, 11-fold higher CXCR4 expression was demonstrated at the oxidized implants compared to the level at machined implants. CXCR4 together with its exclusive ligand, stromal derived factor-1alpha (SDF-1a), has recently gained significant attention as a major axis for local and systemic recruitment of MSCs to sites of tissue repair and regeneration ( $\mathrm{Yu}$, Li et al. ; Ceradini, Kulkarni et al. 2004; Shichinohe, Kuroda et al. 2007; Wang, Deng et al. 2008). Blocking of CXCR4 significantly inhibited in vivo migration of circulating alkaline phosphatase (ALP) positive osteoblast progenitor cells to subcutaneously implanted BMP-2 containing collagen pellets (Otsuru, Tamai et al. 2008). Other studies have also demonstrated that MSC migration to a fractured tibia site is highly dependent on CXCR4 in a time- and dose-dependent manner (GraneroMolto, Weis et al. 2009). The revealed upregulation of the chemokine CXCR4 at the oxidized implant surface was corroborated by SEM and immunohistochemical observations showing the predominance of mesenchymal stem cells at that surface.

At the in vivo bone implant interface, the cellular attachment is meditated via protein rich layer to which cells adhere using variety of surface receptors, mainly form integrin family. The modulation of expression of specific integrins may reflect specific temporal and 
conformational changes in protein adsorption influenced by the physico-chemical properties of the surface. T-shaped hollow titanium implants treated with sulphuric and hydrochloric acids showed higher expression and peak of $\beta 1$ and $\beta 3$ integrins in the surrounding bone after 1 week in rat femur compared to machined titanium and non implant defect (Ogawa and Nishimura 2003). Cells adherent to oxidized surfaces showed upregulation of integrin$\beta 1$ during the 24 hours of implantation (Omar, Lenneras et al. 2010). Since CXCR4 exhibited association with integrin- $\beta 1$ at the oxidized implants, this together with the increased expression of osteogenic markers, such as ALP and osteocalcin (OC), and the higher number of mesenchymal cells, as shown in SEM observations, altogether suggested that the oxidized implant was associated with higher recruitment of MSCs through mechanisms which involve modulation of CXCR4 chemokine receptor and integrin- $\beta 1$ expression (Figure 11). Integrin- $\beta 2$, expressed mainly by leukocytes (Stewart, Thiel et al. 1995) and not by cells of osteoblastic lineage (Hughes, Salter et al. 1993), was higher at the oxidized implants after 12 hours of implantation. This integrin has also been shown to be expressed by osteoclast progenitors (Hayashi, Nakahama et al. 2008). Results showing a higher expression of osteoclastic marker (cathepsin K; CATK) at the oxidized surface (Omar, Svensson et al. 2010) suggested that the higher expression of $\beta 2$ integrin may be due to the early presence of osteoclasts in the interface.
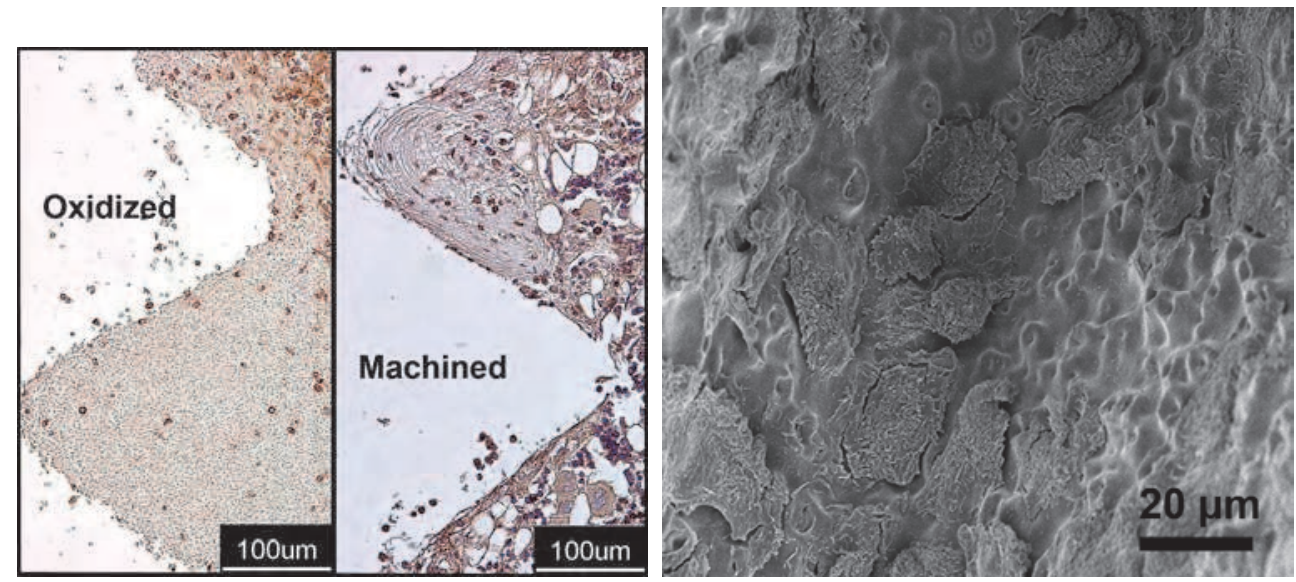

Fig. 11. Left, immunohistochemical sections of the interface $24 \mathrm{~h}$ after implantation showing periostin positive mesenchymal and osteoprogenitor cells. Right, scanning electron microscopy of oxidized implant retrieved $24 \mathrm{~h}$ after implantation. On the oxidized implants, mesenchymal cells were frequently seen.

Peak expression for ALP, OC, tartrate resistant acid phosphatase (TRAP) and CATK was detected 3 days after implantation in rat bone (Omar, Svensson et al. 2010). Previous studies in bone fracture model (without implants) in similar animal model have shown that ALP and OC expression attained their peaks after 5 and 11 days, respectively (Jingushi and Bolander 1990). Osteoclastic gene expression levels of TRAP and CATK have been shown to attain their earliest peaks between 7 - 14 days (Uusitalo, Hiltunen et al. 2000; Nagashima, Sakai et al. 2005). The observations that the peak expression of osteogenic and osteoclastic markers was detected as early as 3 days at the implant surface and that oxidized implants were associated with significantly higher levels than machined implants indicate, firstly, 
that bone remodeling around implants starts much earlier than what has previously been assumed (mainly based on conclusions from fracture models and in vitro experiments with one cell population), and, secondly, that the implant surface has an influence on the level of expression of bone differentiation and remodeling markers. Possible mechanisms for the accelerated implant-associated bone response include multiple cell participation and crosstalk, influenced by material surface physicochemical properties and topography of the implanted surfaces.

The regulation of gene expression at implant surfaces in vivo is a complex process. It is probably that material properties influence the gene expression of several factors, in addition to the secretion, organization and remodelling of the extracellular matrix components. Thereby these events may further affect key-factors, such as Runx2, which is crucial transcription factor for osteogenic differentiation and bone formation. The higher expression of osteoblast markers, (ALP) and (OC), and osteoclast marker, (CATK), was in parallel to a higher expression of Runx2 at the oxidized surfaces compared to machined ones after 3 days of implantation (Omar, Svensson et al. 2010). Similar results were demonstrated for hydrofluoric acid (HF) etched surface in comparison to similar surface without acid etching (Guo, Padilla et al. 2007). In the latter study, Runx2 expression was evident after 7 days in rat tibia and was associated with higher expression of ALP and bone sialoprotein (BSP). Regulatory effect on the expression of Runx2 was also confirmed for the HF surface in rabbit cortical bone concurrently with higher expression of collagen 1 and OC after 8 weeks of implantation (Monjo, Lamolle et al. 2008). At the implant surface, collagenrich matrix organization together with increased expression of integrin- $\beta 1$ may characterize an important pathway for Runx2 activation and consequently the downstream osteogenic activity and bone formation (Figure 12).

The performance of dental implants is best evaluated with respect to their stability into the implantation site. The in vivo interfacial gene expression model has been successfully combined with removal torsion analysis to determine possible relationship between the molecular events and torque strength at the interface (Omar, Lenneras et al. 2011). Significantly higher and constant increase in removal torque was registered for the oxidized implants throughout the period of $6-28$ days of implantation (Figure 13). At the same time, the increased biomechanical strength at the interface of the oxidized implants was in association with higher expression levels of bone formation genes (OC and Runx2). The increased expression of bone formation genes during this period was coupled with upregulated expression of bone resorption genes (TRAP and CATK). The high expression of bone formation and bone resorption indicated an active remodelling throughout the time periods concomitant with an increasing biomechanical strength of the interface. In agreement, other studies compared the expression of different genes and pull-out force of coin-shaped implants with different hydrofluoric acid modification after 4 weeks in rabbit (Lamolle, Monjo et al. 2009; Taxt-Lamolle, Rubert et al. 2010). The test implant group that showed increased pull-out values, revealed higher expression of OC, collagen 1 and TRAP and decreased expression of TNF- $\alpha$ and IL-6.

On the other hand, low and unchanged values were observed in removal torque strength for the machined implants during the evaluation periods 6, 14 and 28 days. Machined implants were associated with an increased expression of pro-inflammatory cytokines (TNF- $\alpha$ and IL$1 \beta$ ) during the early (week) phase of osseointegration (Omar, Lenneras et al. 2010; Omar, Svensson et al. 2010), observations which were extended also to the later stages of osseointegration (Omar, Lenneras et al. 2011). It has previously been suggested that the 

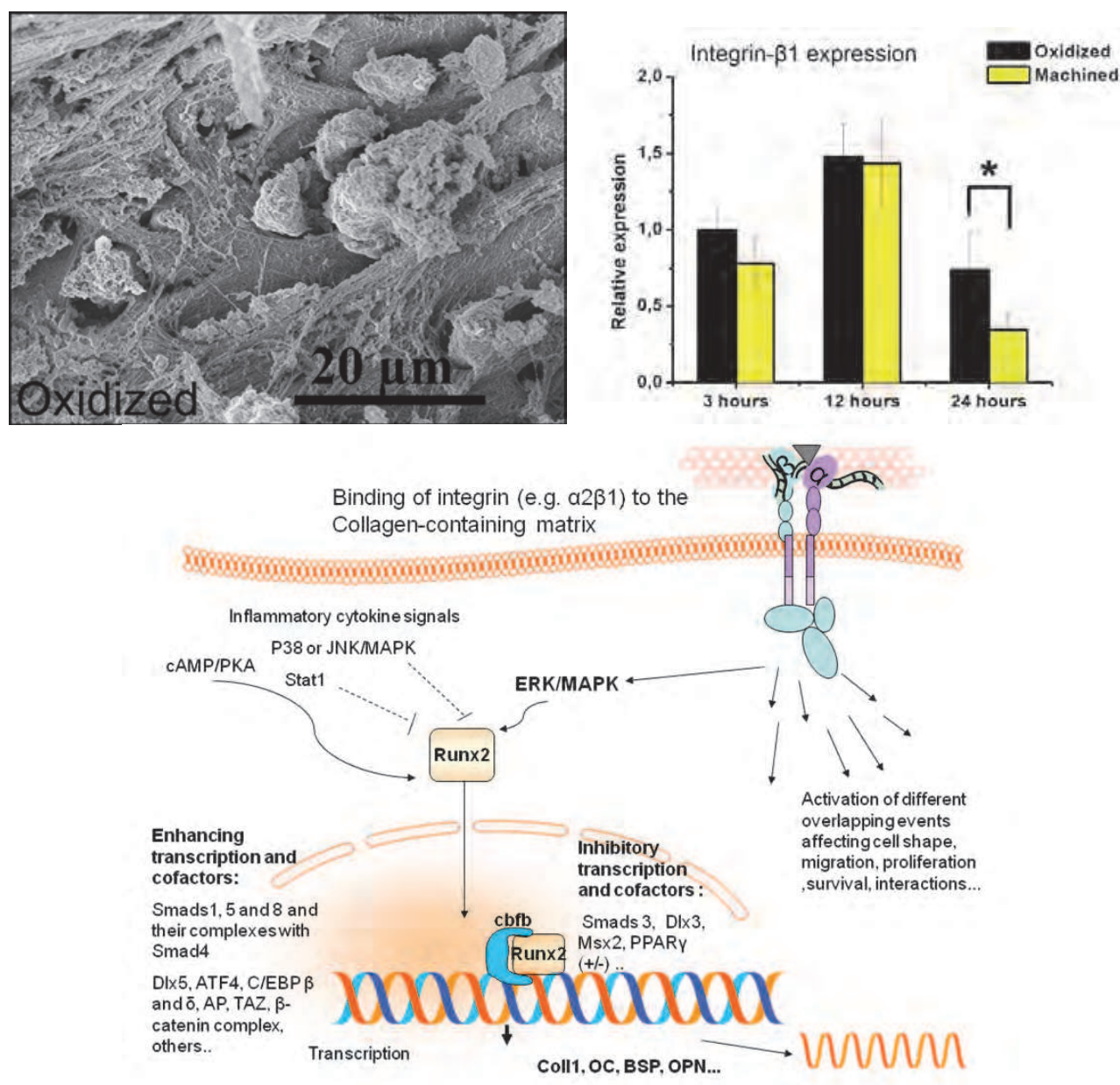

Fig. 12. Upper left, SEM image of oxidized implants retrieved 6d after implantation. Wellorganized collagen network with numerous mesenchymal cells were observed on the oxidized implant. Upper right, a graph showing significantly increased expression of integrin- $\beta 1$ at oxidized implant after $1 \mathrm{~d}$ of implantation. The lower drawing illustrates activation of osteogenic response by mechanisms involving binding of integrin-a2 $\beta 1$ to collagen-rich matrix.

initial reduction and plateauing of the biomechanical strength of machined implants could be a manifestation of post-surgical inflammation and the remodelling activity (Branemark, Ohrnell et al. 1997). This is partly supported by the present results, given that machined implants, which were associated with higher expression of pro-inflammatory cytokines, did not reveal any increase in the biomechanical strength between 6 and 28 days. Whereas the increase in remodelling activity coupled with increased bone forming activity were in line with increased interface resistance for similar time periods. 


\begin{tabular}{|c|c|c|c|c|c|c|c|c|}
\hline & \multicolumn{2}{|c|}{ Initial phase } & \multicolumn{3}{|c|}{ Early phase } & \multicolumn{2}{|c|}{ Late phase } \\
\hline & & $3 \mathrm{~h}$ & $12 \mathrm{~h}$ & $1 \mathrm{~d}$ & $3 \mathrm{~d}$ & $6 \mathrm{~d}$ & $14 \mathrm{~d}$ & $28 \mathrm{~d}$ \\
\hline \multirow{10}{*}{$\begin{array}{l}\text { Ŭ } \\
\text { Ŭ }\end{array}$} & TNF- $\alpha$ & 2-fold at machined & No differnce & 2-fold at machined & No difference & 3-fold at machined & No difference & 3-fold at machined \\
\hline & IL- $\beta 1$ & No difference & No differnce & 5-fold at machined & No difference & 3-fold at machined & 2-fold at machined & 2-fold at machined \\
\hline & MCP-1 & No difference & No difference & 2-fold at machined & Not analyzed & Not analyzed & Not analyzed & Not analyzed \\
\hline & CXCR4 & No difference & 12-fold at oxidized & No difference & Not analyzed & Not analyzed & Not analyzed & Not analyzed \\
\hline & Intg- $\beta 2$ & No difference & 2-fold at oxidized & 2-fold at oxidized & Not analyzed & Not analyzed & Not analyzed & Not analyzed \\
\hline & Runx2 & Not analyzed & Not analyzed & No difference & 6-fold at oxidized & No difference & No difference & 2-fold at oxidized \\
\hline & ALP & Not analyzed & Not analyzed & No difference & 5-fold at oxidized & 2-fold at oxidized & No difference & No difference \\
\hline & $\mathrm{OC}$ & Not analyzed & Not analyzed & No difference & 5-fold at oxidized & 5-fold at oxidized & 3-fold at oxidized & 3-fold at oxidized \\
\hline & CATK & Not analyzed & Not analyzed & No difference & 4-fold at oxidized & 2-fold at oxidized & 2-fold at oxidized & No difference \\
\hline & TRAP & Not analyzed & Not analyzed & No difference & 2-fold at oxidized & 2-fold at oxidized & 2 -fold at oxidized & 2 -fold at oxidized \\
\hline \multicolumn{2}{|c|}{$\begin{array}{l}\text { Scanning electron } \\
\text { microscopy (SEM) } \\
\text { and backscattered } \\
\text { SEM }\end{array}$} & \multicolumn{2}{|c|}{$\begin{array}{l}\text {-Higher proportion of fibrinous material } \\
\text { adherent to machined. } \\
\text {-Larger proportion of mesenchymal cells firmly } \\
\text { anchoring to oxidized. }\end{array}$} & \multicolumn{3}{|c|}{$\begin{array}{l}\text {-Fibrinous material with entrapped leukocytes were evident throughout } \\
\text { the } 6 \text { days at the machined. } \\
\text {-Fairly organized collagenous network and many mesenchymal cells } \\
\text { scattered all over the oxidized at days. }\end{array}$} & \multicolumn{2}{|c|}{$\begin{array}{l}\text {-mineralized lamellar bone and areas of newly } \\
\text { formed bone for both. } \\
\text { - Machined implant: separated from bone by a } \\
\text { narrow gap. } \\
\text {-Oxidized implant: direct contact with bone. Bone } \\
\text { ingrowth into micropores. }\end{array}$} \\
\hline \multicolumn{2}{|c|}{$\begin{array}{l}\text { Histology and } \\
\text { Immuno- } \\
\text {-histochemistry }\end{array}$} & \multicolumn{2}{|c|}{$\begin{array}{l}\text {-Hematoma organization. } \\
\text {-Prominent fibrin mesh at machined. } \\
\text { - CD163 positive cells (Monocytes and } \\
\text { macrophages) at both implants. } \\
\text {-Periostin positive cells (mesenchymal and } \\
\text { osteoprogenitors) at both implants. }\end{array}$} & \multicolumn{3}{|c|}{$\begin{array}{l}\text {-Tissue organization with different cellular populations. } \\
\text {-Higher degree of vascularity and organization at oxidized. } \\
\text {-CD163 positive (Monocytes and macrophages) at both. } \\
\text {-Periostin reactivity (osteoprogenitors and osteoblasts) and throughout } \\
\text { regenerated tissue at both implants. } \\
\text {-Bone formation (woven bone) }\end{array}$} & \multicolumn{2}{|c|}{$\begin{array}{l}\text {-Woven bone remodeled. } \\
\text {-Mature bone forming the interface. }\end{array}$} \\
\hline \multicolumn{2}{|c|}{$\begin{array}{l}\text { Biomechanical } \\
\text { stability }\end{array}$} & \multicolumn{2}{|l|}{ Not analyzed } & \multicolumn{5}{|c|}{$\begin{array}{l}\text {-Oxidized implant demonstrated higher magnitude and significant increase in biomechanical resistance during the first } 28 \text { days. } \\
\text {-Machined implant showed lower magnitude and non-significant increase in biomechanical resistance during the first } 28 \text { days. } \\
\text { - The oxidized implant showed a fracture-like breakpoint while the machined implant showed the typical curve with mainly } \\
\text { separation in the immediate bone-implant interface. }\end{array}$} \\
\hline \multicolumn{2}{|c|}{$\begin{array}{l}\text { Biological } \\
\text { processes }\end{array}$} & \multicolumn{2}{|c|}{$\begin{array}{l}\text { Clot formation, hematoma organization, initial } \\
\text { inflammation, multiple cell chemotaxis and } \\
\text { recruitment and adhesion }\end{array}$} & \multicolumn{3}{|c|}{$\begin{array}{l}\text { Downregulation of inflammatory phase, growth factor production, } \\
\text { tissue organization, differentiation of osteogenic and osteoclastic cells, } \\
\text { coupled bone formation and remodeling }\end{array}$} & \multicolumn{2}{|c|}{$\begin{array}{l}\text { Mature osteoclasts and osteoblasts, continuous } \\
\text { coupled bone formation and remodeling } \\
\text { (maturation), later abating of remodeling, Steady } \\
\text { inflammatory milieu. }\end{array}$} \\
\hline
\end{tabular}

Table 3. Summary of cellular and molecular activities at oxidized and machined implant during the first 4 weeks of implantation in rat tibia. The biological activities were correlated to the biomechanical stability of oxidized and machined implants in the same animal model.

\section{Ultrastructure characterization of bone-implant interface}

In order to further understand the bonding mechanisms that occur between living bone tissue and implant surface, analytical tools with sufficient resolution for ultrastructural analysis are needed. This especially important with the emerging nano-structured implant surfaces. Further, not only the structural aspect should be considered but also the chemical nature of the interface layer is of importance. The tool of choice is transmission electron microscopy (TEM) where various analytical tools often are readily used in high resolution. The electron-solid interaction generates different contrast phenomena, depending on crystal structure and atom number as well as interactions with the sample electrons generating energy-losses of the primary electron beam and secondary x-rays for chemical analysis. Further, elastic scattering and interference contrast could also be used for structural analysis. Hence, TEM is a versatile tool alloying structural and chemical analysis with high lateral and volumetric resolution. However, the literature of biomedical implants in bone tissue using TEM is scarce where the main reason is the sample preparation, especially for metallic implants. The sample should be around $100 \mathrm{~nm}$ thick to be electron transparent. Further a balance between contrast and overlapping information occurs, where less contrast is obtained when the sample becomes thinner, while the amount of overlapping information in the sample increases with the thickness.

\subsection{TEM sample preparation methods}

Different methods for sample preparation have been developed and are often optimized for each branch of research. Within the materials research field, polishing techniques, etching and broad ion milling are often employed, while the ultramicrotome is often used for 

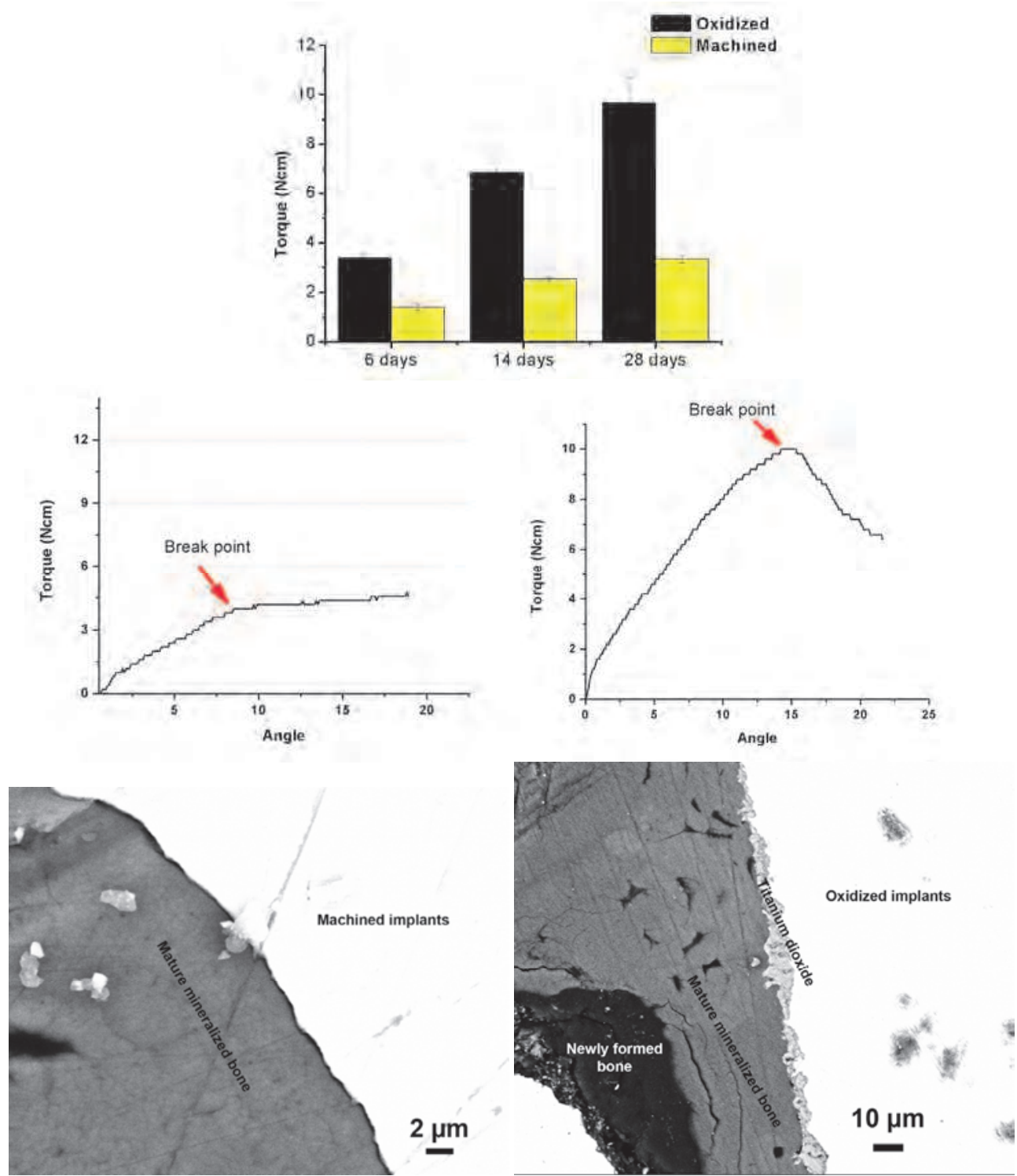

Fig. 13. Upper, a graph showing significant increase in the removal torque values for oxidized implants during early osseointegration. The middle graphs show the loaddeformation curves of machined (left) and oxidized (right) implants after $28 \mathrm{~d}$ of implantation. The deformation of the machined implant interface is mainly due to separation whereas a fracture-like pattern is registered for the oxidized implant. The lower backscattered SEM images show machined implant (left) was separated from bone by a narrow gap. Direct contact of the bone with the oxidized implant (right) was detected with generalized bone ingrowth into different sized micropores. 
tissues. Within the field of biomaterials, the samples are composed of both hard materials as metals and ceramics and tissues as bone and soft tissue, therefore a different strategy has to be employed, as the diamond knife in the ultramicrotome could not cut through the hard implant material and the grinding, etching and broad ion milling will destroy the tissue.

Different strategies have been introduced where the main focus has been focused on removing the uncuttable implant material allowing the use of the ultramicrotome. One of these methods used experimental implants made of plastic which were coated with a thin enough layer of the material that was tested so it was still cuttable with the ultramicrotome. Different metal coating has been used such as titanium, zirconium, gold and steel (Albrektsson et al., 1985, 1982a, 1982b). This method was restricted to experimental studies, as the plastic implants did not posses clinically acceptable mechanical properties. Other methods were developed to be able to evaluate implants from clinical situations where different solutions to remove the implant were used. One method was based on gently fracture away the implant material either during the decalcification step (Steflik et al., 1992) or after resin embedding (Thomsen \& Ericson, 1985). Uncertainties of the integrity of the interfacial tissue remained as the material was completely removed. A strategy for keeping the oxide layer intact, having an intact interface, while removing the bulk properties of the implant allowing ultramicrotome sectioning was developed. By electrochemical dissolution of the metallic titanium the oxide layer was still present in the section (Radegran et al., 1991), however, this technique demineralized the tissue (Sennerby et al., 1991). Another metod used was sawing and grinding to remove the bulk metal leaving the surface layer of the implant intact (Leize et al., 2000 ), this may be useful for thicker surface coatings as plasmasprayed titanium, but with most commercially available dental implant rather thin oxides are present. With the use of focused ion beam (FIB) intact bone-implant interfaces could be prepared, allowing both material and tissue analysis (Engqvist et al., 2006).

\subsection{Interface analysis of different surfaces}

Quit few ultrastructural analysis of the bone-implant interface are presented in the literature as compared to the total amount of articles using bone anchored implants. The most published literature evaluates the machined surface or similar smooth surface using mainly the plastic implant replica model or the fracture method. The fracture method has also been used for acid etched implants, while the FIB has mainly been used for the laser-modified implant surface. Some articles evaluate plasma-sprayed surfaces and oxidized surfaces.

\subsubsection{Smooth implant surface}

Different interfaces have been described for machined implants, some dependent on the healing time and some depending on sample preparation method. Most of the analysis showed that an interposed amorphous electron lucent layer of approximalty 20-50 nm was found between the mineralized bone and implant surface (Albrektsson et al., 1985, 1982; Linder et al., 1983). This was often with a poorly mineralized zone of a few hundred $\mathrm{nm}$ containing collagen fibrils prior to the mineralized bone tissue (Albrektsson et al., 1985, 1986). Others found instead an electron dense layer of similar thickness prior to the mineralized bone tissue, either directly at the implant surface (Ayukawa et al., 1998) or with a larger amorphous zone in direct contact with the surface (Sennerby et al., 1991, 1992). Also a direct contact between mineralized bone tissue and implant surface has been reported using different sample preparation techniques (Albrektsson et al., 1981; Brunette et al., 1991; 
Meyer et al., 2004). By the use of high-resolution TEM crystalline hydroxyapatite was found precipitated directly at the implant surface of a machined titanium implant retrieved after 11 years of clinical loading (Palmquist et al., 2008). The sample preparation technique seem to be essential where plastic implant replicas seem to show a predominance for an intervening electron lucent layer, while the fracture technique show a predominance for an electron dense layer and a thicker amorphous zone. With FIB difficulties in sample preparation for smoother implant surfaces is separation between the tissue and implant (Palmquist et al., 2009)., most likely due to shrinkage of the tissue during dehydration (Lawton et al., 1995) and resin embedding, on the other hand this suggests that the separation for the fracture technique occurs at the immediate interface, and it has been shown that low amount of remnants were found on the implant after fracture (Lausmaa \& Linder, 1988).

\subsubsection{Roughened implant surface}

The most studies have been performed using an acid etched surface, increasing the roughness by pitting and the creation of craters in the surface. The results using the fracture technique of acid etched surfaces showed an electron dense layer interposed between the implant surface and the mineralized bone tissue (Steflik et al., 1992a, 1992b, 1998). Further, at areas of less mature bone tissue a zone of mineralized collagen fibril layer was found between the mineralized bone and the electron dense layer (Steflik et al., 1992b, 1998). Further, the use of high-voltage TEM has enabled tracking of the canaliculus which reach the implant surface (Steflik et al., 1992a, 1994). For plasma-sprayed implants and plastic implant replicas of plasma-sprayed implants a direct bone-implant contact has been described at most places as well as an intervening layer with indistinct structure reaching up to $1 \mu \mathrm{m}$ in thickness (Leize, 2000; Hemmerle \& Voegel, 1996). By combining micro and nano topography by the use of laser ablation, an intimate contact between mineralized bone tissue and implant surface oxide has been described (Palmquist et al., 2010) using the FIB technique. Further, elemental analysis showed the presence of calcium and phosphorous in the nano structured surface oxide (Palmquist et al., 2011). The FIB has also been used to analyse the bone-implant interface of a failed dental implant retrieved with smaller amount of bone tissue, the results showed an electron lucent layer closest to the implant surface as well as bone ingrowth in the porous oxide (Giannuzzi et al., 2005, 2007).

\subsubsection{Bioactive implant surface}

The use of bioactive coating may enable a chemical bond between the implant surface and surrounding bone tissue. Most frequently used bioactive coating is hydroxyapatite. Thin sputtered and Plasma-sprayed HA coatings has been shown to form an intimate contact with bone tissue (Engqvist et al., 2006; Grandfield et al., 2011a, 2011b) with minor resorption of the coating. The use of calcium aluminate coating showed also an intimate contact with bone tissue, where different crystalline phase was observed in the coating while the outermost layer of the coating facing the bone tissue was calcium deficient (Palmquist, et al., 2009). Ultrastructural analyses of hydroxyapatite scaffolds and bone tissue have shown the formation of an apatite layer between the collagenous bone and implant surface (Grandfield et al., 2010a). Further, this layer was shown to have a distinct difference in crystal direction from the crystals in the collagenous bone tissue with the used of electron tomography (Grandfield, et al., 2010b). Further, the incorporation of ions in the hydroxyapatite has shown to influence the rate of dissolution and also the rate of bone formation (Porter et., 2004a, 2004b, 2005). 

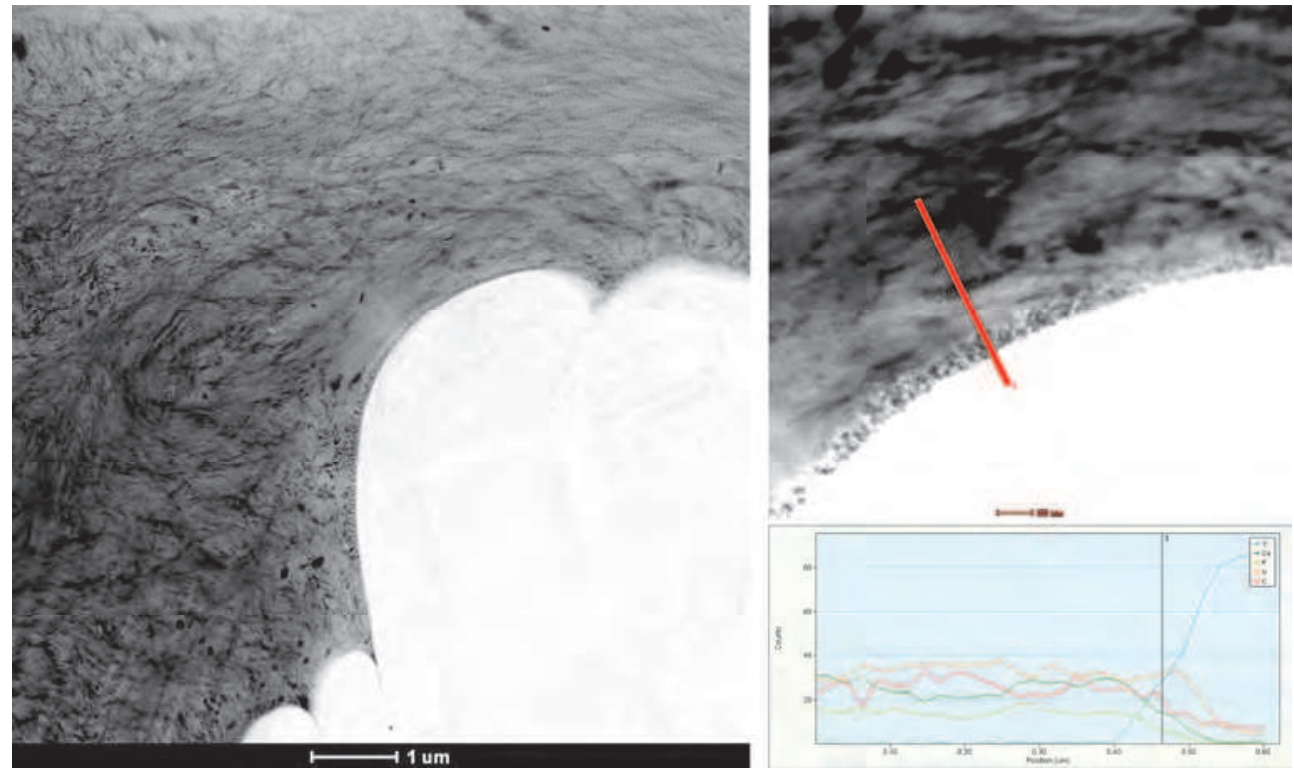

Fig. 14. HAADF-STEM micrographs of laser modified titanium implants after 6 months healing in rabbit, the left image show an overview where bone tissue are found with an intimate contact to the implant surface, collagen banding is observed close to the implant surface. Right, a closer view of the interface, where the enlarged surface oxide is clearly observed with intimate contact to the bone tissue. The EDS line scan along the red line show the presence of Calcium and Phosphorous in the bone tissue, and Titanium in the bulk metal. An overlap zone observed where calcium, phosphorous, titanium and oxygen are seen simultaneously indicating bone ingrowth in the nano structured surface oxide.

\section{Summary}

The new generation dental implants exhibit a large variation in surface properties, both in terms of structural and chemical compositions. The selection criteria for the first generation of dental implants were mainly based on their mechanical properties and corrosion resistance under physiological conditions. The current surfaces have mainly underwent topographical modification and, to a lesser extent, alteration in chemical composition. The aim of surface modifications was to achieve an enhanced biological response. Experimental studies and clinical experience provided extensive empirical knowledge about the role of such surface modifications for biological responses. However, comprehensive understanding of the biological response at the bone-implant interface is still lacking and further research is required to understand the biological processes taking place at the interface, and how these are influenced and can be controlled by specific surface properties.

\section{Future prospective in dental implant surfaces}

Future development of the next, third generation of dental implants should be based on increased knowledge about the interface biology on cellular and molecular levels. The 
development of future generations of oral implants for compromised tissue conditions will, most probably, entail tailored modifications of material surfaces. Implant surfaces, selectively, designed for drug and/or cell releases represent promising candidate strategy. Other surface modifications, such as selective ion substitutions of biomimetic surfaces may further improve the biological response to those surfaces. Further, as the bacterial infection is a major challenge which may jeopardize the success of osseointegrated implants, implant modification resulting in antibacterial activity might be of importance to reduce such complications.

\section{References}

Adell, R; Lekholm, U; Rockler, B. \& Branemark, PI. (1981). A 15-year study of osseointegrated implants in the treatment of the edentulous jaw. Int J Oral Surg, 10, 387-416.

Albrektsson, T; Brånemark PI; Hansson, HA. \& Lindström, J. (1981). Osseointegrated titanium implants. Requirements for ensuring a long-lasting, direct bone-toimplant anchorage in man. Acta Orthop Scand, 52, 155-170.

Albrektsson, T. (1982). Ultrastructural Analysis of the Interface Zone of Titanium and Gold Implants, in Advances in biomaterials, T. Albrektsson, A.J.C. Lee, and P.I. Brånemark, Editors. Wiley: Chichester. p. 167-177.

Albrektsson, T; Hansson, HA. \& Ivarsson B. (1985). Interface analysis of titanium and zirconium bone implants. Biomaterials, 6, 97-101.

Albrektsson, T. \& Hansson, HA. (1986). An ultrastructural characterization of the interface between bone and sputtered titanium or stainless steel surfaces. Biomaterials, 7 , 201-205.

Albrektsson, T; Johansson, C; Lundgren, AK; Sul, YT. \& Gottlow J. (2000). Experimental Studies on Oxidized Implants: A histomorphometrical and biomechanical analysis. Applied Osseointegration Research, 1, 21-24.

Albrektsson, T. \& Wennerberg, A. (2004a). Oral implant surfaces: Part 1--review focusing on topographic and chemical properties of different surfaces and in vivo responses to them. Int J Prosthodont, 17, 536-543.

Albrektsson, T. \& Wennerberg, A. (2004b). Oral implant surfaces: Part 2--review focusing on clinical knowledge of different surfaces. Int J Prosthodont, 17, 544-564.

Ayukawa, Y., et al., (1998). An immunoelectron microscopic localization of noncollagenous bone proteins (osteocalcin and osteopontin) at the bone-titanium interface of rat tibiae. J Biomed Mater Res, 41, 111-9.

Ballo, AM; Xia, W; Lindahl, C; Lausmaa, J; Engqvist, H. \& Thomsen, P. (2010). Bone responses to ions-substituted apatite/titanium dioxide coating on titanium implants. $8^{\text {th }}$ General Session \& Exhibition of the IADR, Barcelona, Spain, July, 2010.

Ballo, AM; Närhi, TO; Akca, EA; Ozen, T; Syrjänen, SM; Lassila, LV. \& Vallittu, PK. (2011). Prepolymerized vs. in situ-polymerized fiber-reinforced composite implants--a pilot study. J Dent Res, 90, 263-267.

Ballo, AM; Akca, EA; Ozen, T; Lassila, L; Vallittu, PK. \& Närhi TO. (2009). Bone tissue responses to glass fiber-reinforced composite implants--a histomorphometric study. Clin Oral Implants Res, 20, 608-15. 
Barrere, F; Snel, MME; van Blitterswijk, CA; de Groot, K. \& Layrolle, P. (2004). Nano-scale study of the nucleation and growth of calcium phosphate coating on titanium implants. Biomaterials, 25, 2901-2910.

Barrere, F; van der Valk, CM; Meijer, G; Dalmeijer, RA., De Groot, K. \& Layrolle, P. (2003). Osteointegration of biomimetic apatite coating applied onto dense and porous metal implants in femurs of goats. Journal of Biomedical Materials Research 67: 655-665.

Bloyer, DR; Gomez-Vega, JM; Saiz, E; Mcnaney, JM; Cannon, RM. \& Tomsia, AP. (1999). Fabrication and characterization of a bioactive glass coating on titanium implant aloys, Acta mater, 47, 4221-4224.

Brånemark, R; Brånemark, PI; Rydevik, B. \& Myers RR. (2001). Osseointegration in skeletal reconstruction and rehabilitation: a review. J Rehabil Res Dev, 38, 175-181.

Brånemark, PI; Hansson, BO; Adell, R; Breine, U; Lindstrom, J; Hallen, O. \& Ohman A. (1977). Osseointegrated implants in the treatment of the edentulous jaw. Experience from a 10-year period. Scand J Plast Reconstr Surg Suppl, 16, 1-132.

Brånemark, R; Emanuelsson, L; Palmquist, A. \& Thomsen, P. (2010). Bone response to laserinduced micro- and nano-size titanium surface features. Nanomedicine. (In press)

Brånemark, R; Ohrnell, LO; Nilsson, P. \& Thomsen, P. (1997). Biomechanical characterization of osseointegration during healing: an experimental in vivo study in the rat. Biomaterials, 18, 969-978.

Brånemark, PI; Adell, R; et al. (1969). Intra-osseous anchorage of dental prostheses. I. Experimental studies. Scand J Plast Reconstr Surg, 3, 81-100.

Brunette, DM; Ratkay, J. \& Chehroudi B. (1991). Behaviour of Osteoblasts on Micromachined Surfaces, in: The bone-biomaterial interface, J.E. Davies, Editor, Univ. of Toronto Press: Toronto. p. 425-437.

Brunette, DM; Tengvall, P; Textor, M. \& Thomsen, P. (eds) (2001). Titanium in medicine: material science, surface science, engineering, biological responses, and medical applications. Berlin, Germany: Springer.

Buser, D; Broggini, N; Wieland, M; Schenk, RK; Denzer, AJ; Cochran, DL; Hoffmann, B; Lussi, A. \& Steinemann, SG. (2004). Enhanced bone apposi-tion to a chemically modified SLA titanium surface. J Dent Res, 83, 529-533.

Buser, D; Schenk, RK; Steinemann, S; Fiorellini, JP; Fox, CH. \& Stich, H. (1991). Influence of surface characteristics on bone integration of titanium implants. A histomorphometric study in miniature pigs. J Biomed Mater Res, 25, 889-902.

Buser, D; Nydegger, T; Oxland, T; Cochran, DL; Schenk, RK; Hirt, HP; Snétivy, D. \& Nolte, LP. (1999). Interface shear strength of titanium implants with a sandblasted and acid-etched surface: a biomechanical study in the maxilla of miniature pigs. J Biomed Mater Res, 45, 75-83.

Cao, W. \& Hench, LL. (1996). Bioactive Materials. Ceramics International, 22, 493-507.

Carr, AB ; Larsen, PE ; Papazoglou, E. \& McGlumphy, E. (1995). Reverse torque failure of screw-shaped implants in baboons: baseline data for abutment torque application. Int J Oral Maxillofac Implant, 10, 167-174.

Celletti, R; Marinho, VC; Traini, T; Orsini, G; Bracchetti, G; Perrotti, V, et al. (2006). Bone contact around osseointegrated implants: a histologic study of acid-etched and machined surfaces. J Long Term Eff Med Implants, 16, 131-143. 
Ceradini, DJ; Kulkarni, AR et al. (2004). Progenitor cell trafficking is regulated by hypoxic gradients through HIF-1 induction of SDF-1. Nat Med, 10, 858-864.

Chehroudi, B; Ratkay, J. \& Brunette, DM. (1992). The role of implant surface geometry on mineralization in vitro and in vivo: a transmission and electronmicroscopic study. Cells Mater, 2, 89-104.

Cook, SD; Kay, JF. \& Thomas, KA. (1987). Interface mechanics and histology of titanium and HA-coated titanium for dental implant applications. Int J Oral Maxillofac Implants, 2, 15-22.

Cooper, LF; Masuda, T; Yliheikkila, PK. \& Felton, DA. (1998). Generalizations regarding the process and phenomenon of osseointegration. Part 2: in vitro studies. J Oral Maxillofac Implants, 13, 163-174.

Cooper, LF; Zhou, Y; Takebe, J; Guo, J; Abron, A; Holmen, A, et al. (2006). Fluoride modification effects on osteoblast behavior and bone formation at $\mathrm{TiO} 2$ grit-blasted c.p. titanium endosseous implants. Biomaterials, 27, 926-936.

Conforto, E; Caillard, D; Aronsson, BO. \& Descouts, P. (2004). Crystallographic properties and mechanical behaviour of titanium hydride layers grown on titanium implants. Philosophical Magazine, 84, 631-645.

Cochran, DL; Schenk, RK; Lussi, A; Higginbottom, FL. \& Buser, D. (1998). Bone response to unloaded and loaded titanium implants with a sandblasted and acid-etched surface: A histomorphometric study in the canine mandible. Journal of Biomedical Materials Research, 40, 1-11.

Davies, JE. (2003). Understanding peri-implant endosseous healing. Journal of Dental Education, 67, 932-949.

De Groot, K; Geesink, R; Klein, CP. \& Serekian, P. (1987). Plasma sprayed coatings of hydroxylapatite. J Biomed Mater Res, 21, 1375-1381.

Denissen, HW; Kalk, W; De Nieuport, HM; Maltha, JC. \& Van de Hooff, A. (1990). Mandibular bone response to plasma-sprayed coating of hydroxyapatite. Int J Prosthodont, 3, 53-58.

Ding, S. (2003). Properties and immersion behavior of magnetrons puttered multi-layered hydroxyapatite/titanium composite coatings. Biomaterials, 24, 4233-4238.

Ding, S; Ju, C. \& Lin, JC. (1999). Characterization of hydroxyapatite and titanium coatings sputtered on Ti-6Al-4V substrate. J Biomed Mater Res, 44, 266-279.

Elias, CN; Oshida, Y; Lima, JH. \& Muller, CA. (2008). Relationship between surface properties (roughness, wettability and morphology) of titanium and dental implant removal torque. J Mech Behav Biomed Mater, 1, 234-42.

Ellingsen, JE; Johansson, CB; Wennerberg, A. \& Holmen, A. (2004). Improved retention and bone-tolmplant contact with fluoride-modified titanium implants. Int J Oral Maxillofac Implants, 19, 659-666.

Engqvist, H., et al., (2006). A novel tool for high-resolution transmission electron microscopy of intact interfaces between bone and metallic implants. J Biomed Mater Res A, 78, 20-24.

Esposito, M; Coulthard, P; Thomsen, P. \& Worthington, HV. (2005). The role of implant surface modifications, shape and material on the success of osseointegrated dental implants. A Cochrane systematic review. Eur J Prosthodont Restor Dent, 13, 15-31. 
Esposito, M; Worthington, HV; Thomsen, P. \& Coulthard, P. (2003). Interventions for replacing missing teeth: different types of dental implants. Cochrane Database Syst Rev, CD003815.

Frayssinet, P ; Trouillet, JL ; Rouquet, N ; Azimus, E. \& Autefage, A. (1993). Osseointegration of macroporous calcium phosphate ceramics having a different chemical composition. Biomaterials, 14, 423-429.

Frojd, V; Franke-Stenport, V; Meirelles, L. \& Wennerberg, A. (2008). Increased bone contact to a calcium-incorporated oxidized commercially pure titanium implant: an in-vivo study in rabbits. Int J Oral Maxillofac Surg, 37, 561-566.

Fuming, H; Guoli, Y; Xiaoxiang, W. \& Shifang, Z. (2008). The removal torque of titanium implant inserted in rabbit femur coated with biomimetic deposited Ca-P coating. J Oral Rehabil. 35, 754-65.

Furlong, RJ. \& Osborn, JF. (1991). Fixation of hip prostheses by hydroxyapatite ceramic coatings. J Bone Jt Surg, 73, 741-745.

Gadelmawla, ES; Koura, MM; Maksoud, TMA; Elewa, IM. \& Soliman, HM. (2002). Roughness parameters. Journal of Materials Processing Technology, 123, 133-145.

Giannuzzi, LA; Giannuzzi, NJ. \& Capuano, MJ. (2005). FIB, SEM, and TEM of Bone/Dental Implant Interfaces. Microscopy and Microanalysis, 11, 998-999.

Giannuzzi, LA; Phifer, D; Giannuzzi, NJ. \& Capuano, MJ. (2007). Two-dimensional and 3dimensional analysis of bone/dental implant interfaces with the use of focused ion beam and electron microscopy. J Oral Maxillofac Surg, 65, 737-747.

Gomez-Vega, JM; Hozumi, A; Saiz, E; Tomsia, AP; Sugimura, H. \& Takai, O. (2001). Bioactive glass-mesoporous silica coatings on Ti6Al4V throgh enameling and triblock-copolymer-templated sol-gel processing, J Biomed Mater Res, 56, 382-389.

Gomez-Vega, JM; Saiz, E; Tomsia, AP; Marshall, GW. \& Marshall, SJ. (2000a). Bioactive glass coatings with hydroxyapatite and Bioglass particles on Ti-based implants. I. Processing, Biomaterials, 21, 105-111.

Gomez-Vega, JM; Saiz, E; Tomsia, AP; Oku, T; Suganuma, K; Marshall, GW. \& Marshall, SJ. (2000b). Novel bioactive glass functionally graded coatings on Ti6Al4V, Adv Mater, $12,894-898$.

Gottlow, J; Johansson, C; Albrektsson, T. \& Lundgren, AK. (2010). Biomechanical and Histological Evaluation of the TiUnite and Osseotite Implant Surfaces in Rabbits after 6 Weeks of Healing. Applied Osseointegration Research, 1, 25-27.

Grandfield, K., et al. (2011a)., Ultrastructural characterization of the hydroxyapatite-coated pedicle screw and human bone interface. Int J Nano and Biomaterials. Accepted for publication.

Grandfield, K., et al. (2011b)., Free form fabricated features on CoCr implants with and without hydroxyapatite coating in vivo: a comparative study of bone contact and bone growth induction. J Mater Sci Mater Med. Accepted for publication

Grandfield, K., et al. (2010a)., Bone Response to Free-Form Fabricated Hydroxyapatite and Zirconia Scaffolds: A Transmission Electron Microscopy Study in the Human Maxilla. Clinical implant dentistry and related research. Accepted for publication.

Grandfield, K., et al., (2010b). Visualizing biointerfaces in three dimensions: electron tomography of the bone-hydroxyapatite interface. J R Soc Interface, 7, 1497-1501. 
Greenspan, DC. \& Hench, LL. (1976). Chemical and mechanical behavior of bioglass-coated alumina. J Biomed Mater Res, 10, 503-509.

Granero-Molto, FJA; Weis, et al. (2009). Regenerative effects of transplanted mesenchymal stem cells in fracture healing. Stem Cells, 27, 1887-1898.

Guo, J., R. J. Padilla, et al. (2007). The effect of hydrofluoric acid treatment of $\mathrm{TiO}_{2}$ grit blasted titanium implants on adherent osteoblast gene expression in vitro and in vivo. Biomaterials, 28, 5418-5425.

Habibovic, P; Barrère, F; van Blitterswijk, CA; Groot, K. \& Layrolle, P. (2002). Biomimetic Hydroxyapatite Coating on Metal Implants. J. Am. Ceram. Soc, 85, 517-522.

Hayashi, H; Nakahama, K; et al. (2008). The role of Mac-1 (CD11b/CD18) in osteoclast differentiation induced by receptor activator of nuclear factor-kappaB ligand. FEBS Lett, 582, 3243-3248.

Hall, J. \& Lausmaa, J. (2000). Properties of a new porous oxide surface on titanium implants. Applied Osseointegration Research, 1, 5-8.

Hayakawa, T; Yoshinari, M; Nemoto, K; Wolke, JGC. \& Jansen, JA. (2000). Effect of surface roughness and calcium phosphate coating on the implant/bone response. Clin Oral Implant Res, 11, 296-304.

He, F; Liu, L; Zhao, S; Zhao, S; Chen, S. \& Wang, X. (2007). Fast formation of biomimetic apatite coatings on pure porous titanium implant's surface. Sheng Wu Yi Xue Gong Cheng Xue Za Zhi, 24, 806-811.

He, F; Yang, G; Wang, X. \& Zhao, S. (2009). Bone responses to rough titanium implants coated with biomimetic Ca-P in rabbit tibia. J Biomed Mater Res B Appl Biomater, 90, 857-63.

Hemmerle, J; Onçag, A. \& Ertürk S. (1997). Ultrastructural features of the bone response to a plasma-sprayed hydroxyapatite coating in sheep. J Biomed Mater Res, 36:418425.

Hemmerle, J. \& Voegel, JC. (1996). Ultrastructural aspects of the intact titanium implantbone interface from undecalcified ultrathin sections. Biomaterials, 17, 1913-1920.

Hench, LL; Splinter, RJ; Allen, WC. \& Greenlee, TK. (1971) Bonding mechanisms at the interface of ceramic prosthetic materials. J Biomed Mater Res Symposium, 2, 11741.

Hench, LL. \& Andersson, ÖH. (1993). Bioactive glass coatings. In Hench LL and Wilson J editors. An introduction to bioceramics, World Scientific, 239.

Henry, PJ; Tan, AES; Allan, BP; Hall, J. \& Johansson C. (2000). Removal Torque Comparison of TiUnite and Turned Implants in the Greyhaound Dog Mandible. Applied Osseointegration Research, 1, 15-17.

Hughes, DE; Salter DM; , et al. (1993). Integrin expression in human bone. J Bone Miner Res, $8,527-533$.

Jansen, JA; van de Waerden, JP; Wolke, JG. \& de Groot, K. (1991). Histologic evaluation of the osseous adaptation to titanium and hydroxyapatite-coated titanium implants J Biomed Mater Res, 25, 973-989.

Jansen, JA; Wolke, JGC; Swann, S; van der Waerden, JPCM. \& de Groot K. (1993). Application of magnetron-sputtering for producing ceramic coatings on implant materials. Clinical Oral Implants Research, 4, 28-34. 
Jansson, E; Kalltorp, M; et al. (2002). Ex vivo PMA-induced respiratory burst and TNF-alpha secretion elicited from inflammatory cells on machined and porous blood plasma clot-coated titanium. Biomaterials, 23, 2803-2815.

Jarmar, T; Palmquist, A; Branemark, R, Hermansson, L; Engqvist, H. \& Thomsen, P. (2008). Characterization of the surface properties of commercially available dental implants using scanning electron microscopy, focused ion beam, and highresolution transmission electron microscopy. Clin Implant Dent Relat Res, 10, 1122.

Jingushi, S. \& Bolander ME. (1990). Biological Cascades of Fracture Healing as Models for Bone-Biomaterial Interface. The Bone-Biomaterial Interface. J. E. Davies. Toronto, University of Toronto Press: 250-262.

Jungner, M; Lundqvist, P. \& Lundgren, S. (2005). Oxidized titanium implants (Nobel Biocare TiUnite) compared with turned titanium implants (Nobel Biocare mark III) with respect to implant failure in a group of consecutive patients treated with early functional loading and two-stage protocol. Clin Oral Implants Res, 16, 308-312.

Kasemo, B. \& Lausmaa, J. (1988). Biomaterial and implant surfaces: a surface science approach. Int J Oral Maxillofac Implants, 3, 247-259.

Kitsugi, T; Nakamura, T; Oka, M; Senaha, Y; Goto, T. \& Shibuya, T. (1996). Bone-bonding behavior of plasma-sprayed coatings of BioglassR, AW-glass ceramic, and tricalcium phosphate on titanium alloy. J Biomed Mater Res, 30, 261-269.

Klokkevold, PR; Johnson, P; Dadgostari, S; Caputo, A; Davies, JE. \& Nishimura, RD. (2001). Early endosseous integration enhanced by dual acid etching of titanium: a torque removal study in the rabbit. Clin Oral Implants Res, 12, 350-357.

Kokubo, T; Kushitani, H; Sakka, S; Kitsugi, T. \& Yamamuro, T. (1990). Solutions able to reproduce in vivo surface-structure changes in bioactive glass-ceramic A-W. J Biomed Mater Res, 24, 721-734.

Lacefield, WR. \& Hench, LL. (1986). The bonding of Bioglass to a cobalt-chromium surgical implant alloy. Biomaterials, 7, 104-108.

Lamolle, SF ; Monjo, M ; et al. (2009). Titanium implant surface modification by cathodic reduction in hydrofluoric acid: surface characterization and in vivo performance. J Biomed Mater Res A, 88, 581-588.

Larsson, C; Esposito, M; et al. (2001). The Titanium-Bone Interface In Vivo. Titanium in Medicine. D. M. Brunette, P. Tengvall, M. Textor and P. Thomsen. New York, Springer, 587-648.

Lausmaa, J. \& Linder, L. (1988). Surface spectroscopic characterization of titanium implants after separation from plastic-embedded tissue. Biomaterials, 9, 277-280.

Lausmaa J. (1996). Surface spectroscopic characterization of titanium implant materials. Journal of Electron Spectroscopy and Related Phenomena, 81, 343-361.

Lausmaa J. (2001). Mechanical, Thermal, Chemical and Electrochemical Surface Treatment of Titanium. In: Brunette DM, editor. Titanium in medicine : material science, surface science, engineering, biological responses and medical applications. Berlin: Springer, 1019.

Lawton, DM; Oswald, WO. \& McClure, J. (1995). The biological reality of the interlacunar network in the embryonic, cartilaginous, skeleton: a thiazine dye/absolute ethanol/LR White resin protocol for visualizing the network with minimal tissue shrinkage. J Microsc, 178, 66-85. 
Leize, EM; Hemmerle, J. \& Leize, M. (2000). Characterization, at the bone crystal level, of the titanium-coating/bone interfacial zone. Clin Oral Implants Res, 11, 279-288.

Linder, L., et al., (1983). Electron microscopic analysis of the bone-titanium interface. Acta Orthop Scand, 54, 45-52.

Ma, J; Huifen, W; Kong, LB. \& Peng, KW. (2003). Biomimetic processing of nanocrystallite bioactive apatite coating on titanium. Nanotechnology, 14, 619-623.

Masaki, C ; Schneider, GB ; et al. (2005). Effects of implant surface microtopography on osteoblast gene expression. Clin Oral Implants Res, 16, 650-656.

Meyer, U., et al., (2004). Ultrastructural characterization of the implant/bone interface of immediately loaded dental implants. Biomaterials, 25, 1959-1967.

Mistry, S; Kundu, D; Datta, S. \& Basu, D. (2011). Comparison of bioactive glass coated and hydroxyapatite coated titanium dental implants in the human jaw bone. Aust Dent J, 56, 68-75.

Monjo, M ; Lamolle, SF ; et al. (2008). In vivo expression of osteogenic markers and bone mineral density at the surface of fluoride-modified titanium implants. Biomaterials, 29, 3771-3780.

Morris, HF; Ochi, S; Spray, JR. \& Olson, JW. (2000). Periodontal-type measurements associated with hydroxyapatite-coated and non-HA-coated implants: uncovering to 36 months. Annals of Periodontology/the American Academy of Periodontology, $5,56-67$.

Muller, FA; Jonasova, L; Helebrant, A; Strnad, J. \& Greil, P. (2004). Biomimetic apatite formation on chemically treated titanium. Biomaterials, 25, 1187.

Nagashima, M; Sakai, A; et al. (2005). Bisphosphonate (YM529) delays the repair of cortical bone defect after drill-hole injury by reducing terminal differentiation of osteoblasts in the mouse femur. Bone, 36, 502-511.

Nygren, H; Tengvall, P. et al. (1997). The initial reactions of $\mathrm{TiO} 2$ with blood. J Biomed Mater Res, 34, 487-492.

Ogawa, T. \& Nishimura I. (2003). Different bone integration profiles of turned and acidetched implants associated with modulated expression of extracellular matrix genes. Int J Oral Maxillofac Implants, 18, 200-210.

Oku, T; Suganuma, K; Wallenberg, LR; Tomsia, AP; Gomez-Vega, JM. \& Saiz, E. (2001). Structural characterization of the metal/glass interface in bioactive glass coatings on Ti-6Al-4V, J Mat Sci Mat Med, 12, 413-417.

Omar, O. (2010). Mechanisms of Osseointegration: Experimental Studies on Early Cellular and Molecular Events in vivo [Doctoral thesis]. Göteborg: University of Gothenburg.

Omar, O; Svensson, S; Lennerås, M; Zoric, N; Suska, F; Hall, J; Nannmark, U, \& Thomsen, P. (2010). In vivo gene expression at anodically oxidized versus machined titanium implants. J Biomed Mater Res, 92, 1552-1566.

Omar, O ; Lenneras, M. et al. (2010). Integrin and chemokine receptor gene expression in implant-adherent cells during early osseointegration. J Mater Sci Mater Med, 21, 969-980.

Omar, O; Lenneras, ME. et al. (2011). The correlation between gene expression of proinflammatory markers and bone formation during osseointegration with titanium implants. Biomaterials, 32, 374-386. 
Ong, JL; Raikar, GN. \& Smoot, TM. (1997). Properties of calcium phosphate coatings before and after exposure to simulated biological fluid. Biomaterials, 18, 1271-1275.

Ong, JL. \& Lucas, LC. (1998). Auger electron spectroscopy and it use for the characterization of titanium and hydroxyapatite surfaces. Biomaterials, 19, 455-64.

Ong, JL; Bessho, K; Cavin, R. \& Carnes, DL. (2002). Bone response to radio frequency sputtered calcium phosphate implants and titanium implants in vivo. J Biomed Mater Res, 59, 184-190.

Otsuru, S; et al. (2008). Circulating bone marrow-derived osteoblast progenitor cells are recruited to the bone-forming site by the CXCR4/stromal cell-derived factor-1 pathway. Stem Cells, 26, 223-234.

Palmquist, A; et al., (2009). Calcium aluminate coated and uncoated free form fabricated CoCr implants: A comparative study in rabbit. J Biomed Mater Res B Appl Biomater, 91, 122-127.

Palmquist, A; et al., (2010). Biomechanical, histological, and ultrastructural analyses of laser micro- and nano-structured titanium alloy implants: A study in rabbit. J Biomed Mater Res A, 92, 1476-1486.

Palmquist, A; et al., (2009). Morphological studies on machined implants of commercially pure titanium and titanium alloy (Ti6Al4V) in the rabbit. J Biomed Mater Res B Appl Biomater, 91, 309-319.

Palmquist, A; Jarmar, T; Emanuelsson, L; Branemark, R; Engqvist, H. \& Thomsen P. (2008). Forearm bone-anchored amputation prosthesis: a case study on the osseointegration. Acta Orthop, 79, 78-85.

Palmquist, A., et al., (2011). Biomechanical, Histological and Ultrastructural Analyses of Laser Micro- and Nano-structured Titanium implant after 6 months in rabbit. J Biomed Mater Res B Appl Biomater, Accepted for publication.

Park, JY; \& Davies., JE. (2000). Red blood cell and platelet interactions with titanium implant surfaces. Clin Oral Implants Res, 11, 530-539.

Porter, A., et al., (2005). Effect of carbonate substitution on the ultrastructural characteristics of hydroxyapatite implants. J Mater Sci Mater Med, 16, 899-907.

Porter, AE; Best, SM. \& Bonfield, W. (2004). Ultrastructural comparison of hydroxyapatite and silicon-substituted hydroxyapatite for biomedical applications. J Biomed Mater Res A, 68, 133-41.

Porter, AE; et al., (2004). Ultrastructural comparison of dissolution and apatite precipitation on hydroxyapatite and silicon-substituted hydroxyapatite in vitro and in vivo. J Biomed Mater Res A, 69, 670-679.

Radegran, G; Lausmaa, J; Mattsson, L; Rolander, U. \& Kasemo, B. (1991). Preparation of ultra-thin oxide windows on titanium for TEM analysis. J Electron Microsc Tech, 19, 99-106.

Robinson, K; Brånemark, R. \& Ward, D. (2004). Future Developments: Osseointegration in Transfemoral Amputees. In: Smith D, Michael J, Bowker J, editors. Atlas of Amputations and Limb Deficiencies: Surgical, Prosthetic and Rehabilitation Principles. Third Edition ed, 673-681.

Rosenberg, ES; Torosian, JP. \& Slots, J. (1991). Microbial differences in 2 clinically distinct types of failures of osseointegrated implants. Clin Oral Implants Res, 2, 135-144. 
Rupp, F; Scheideler, L; Olshanska, N; de Wild, M; Wieland, M. \& Geis-Gerstorfer, J. (2006). Enhancing surface free energy and hydrophilicity through chemical modification of microstructured titanium implant surfaces. J Biomed Mater Res A, 76, 323-334.

Rydevik. B. (1997). Amputation prostheses and osseoperception in the lower and upper extremity. In: Brånemark P-I, Rydevik B, Skalak R, editors. Osseointegration in skeletal reconstruction and joint replacement. London: Guintessence Books, 175182.

Saiz, E; Goldman, M; Gomez-Vega, JM; Tomsia, AP; Marshall, GW. \& Marshall, SJ. (2002). In vitro behaviour of silicate glass coatings on Ti6Al4V, Biomaterials, 23, 37493756.

Schepers, E; Ducheyne, P; De Clerq, M. (1989). Interfacial analysis of fiber-reinforced bioactive glass dental root implants, J Biomed Mater Res, 23, 735-752.

Schrooten, J. \& Helsen, JA. (2000). Adhesion of bioactive glass coating to Ti6A14V oral implant. Biomaterials, 21, 1461-9.

Schroeder, A; van der, Zypen, E; Stich, H. \& Sutter, F. (1981). The reactions of bone, connective tissue, and epithelium to endosteal implants with titanium-sprayed surfaces. J Maxillofac Surg, 9, 15-25.

Schupbach, P ; Glauser, R ; Rocci, A; Martignoni, M; Sennerby, L; Lundgren, A. \& Gottlow, J. (2005). The human bone-oxidized titanium implant interface: a light microscopic, scanning electron microscopic, back-scatter scanning electron microscopic, and energy-dispersive X-ray study of clinically retrieved dental implants. Clin Implant Dent Relat Res, 7, 36-43.

Schwarz, F; Herten, M; Sager, M; Wieland, M; Dard, M. \& Becker, J. (2007). Bone regeneration in dehiscence-type defects at chemicallymodified (SLActive) and conventional SLA titanium implants:A pilot study in dogs. J Clin Periodontol, 34, 78-86.

Shichinohe, H; Kuroda, S; et al. (2007). Role of SDF-1/CXCR4 system in survival and migration of bone marrow stromal cells after transplantation into mice cerebral infarct. Brain Res, 1183, 138-147.

Sennerby, L; Ericson, LE; Thomsen, P; Lekholm, U. \& Astrand, P. (1991). Structure of the bone-titanium interface in retrieved clinical oral implants. Clin Oral Implants Res, 2, 103-111.

Sennerby, L; Thomsen, P; et al. (1993). Early tissue response to titanium implants inserted in rabbit cortical bone. Part I Light microscopic observations. Journal of Materials Science: Materials in Medicine, 4, 240-250.

Sennerby, L; Thomsen, P; et al. (1993). Early tissue response to titanium implants inserted in rabbit cortical bone. Part II Ultrastructural observations. Journal of Materials Science: Materials in Medicine, 4, 494-502.

Sennerby, L; Thomsen, P. \& Ericson, LE. (1992). Ultrastructure of the bone-titanium interface in rabbits. Journal of Materials Science: Materials in Medicine, 3, 262-271.

Steflik, DE; Corpe, RS; Lake, FT; Sisk, AL; Parr, GR; Hanes, PJ; et al. (1997). Composite morphology of the bone and associated support-tissue interfaces to osseointegrated dental implants: TEM and HVEM analyses. Int J Oral Maxillofac Implants, 12, 443453.

Steflik, DE; Corpe, RS; Lake, FT; Young, TR; Sisk, AL; Parr, GR; et al. (1998). Ultrastructural analyses of the attachment (bonding) zone between bone and implanted biomaterials. J Biomed Mater Res, 39, 611-620. 
Steflik, DE; Parr, GR; Sisk, AL; Hanes, PJ. \& Lake, FT. (1992). Electron microscopy of bone response to titanium cylindrical screw-type endosseous dental implants. Int J Oral Maxillofac Implants, 7, 497-507.

Steflik, DE; Sisk, AL; Parr, GR; Lake, FT; Hanes, PJ; Berker; DJ; et al. (1994). Transmission electron and high-voltage electron microscopy of osteocyte cellular processes extending to the dental implant surface. J Biomed Mater Res, 28, 1095-1107.

Steflik, DE; et al., (1992). High-voltage electron microscopy and conventional transmission electron microscopy of the interface zone between bone and endosteal dental implants. J Biomed Mater Res, 26, 529-45.

Stewart, M; Thiel, M; et al. (1995). Leukocyte integrins. Curr Opin Cell Biol, 7, 690-696.

Sul, YT; Johansson, C; Byon, E. \& Albrektsson, T. (2005a). The bone response of oxidized bioactive and non-bioactive titanium implants. Biomaterials, 26, 6720-6730.

Sul, YT; Johansson, C; Wennerberg, A; Cho, LR; Chang, BS. \& Albrektsson, T. (2005b). Optimum surface properties of oxidized implants for reinforcement of osseointegration: surface chemistry, oxide thickness, porosity, roughness, and crystal structure. Int J Oral Maxillofac Implants, 20, 349-59.

Sul, YT; Johansson, C. \& Albrektsson, T. (2006). Which surface properties enhance bone response to implants? Comparison of oxidized magnesium, TiUnite, and Osseotite implant surfaces. Int J Prosthodont, 19, 319-328.

Sun, L; Berndt, CC; Gross, KA. \& Kucuk, A. (2001). Materials fundamentals and clinical performance of plasma-sprayed hydroxyapatite coatings: a review. J Biomed Mater Res (Appl Biomater), 58, 570-92.

Suska, F; Esposito, M; et al. (2003). IL-1alpha, IL-1beta and TNF-alpha secretion during in vivo/ex vivo cellular interactions with titanium and copper. Biomaterials, 24, 461468.

Szmukler-Moncler, S; Perrin, D; Ahossi, V; Magnin, G. \& Bernard, JP. (2004). Biological properties of acid etched titanium implants: effect of sandblasting on bone anchorage. J Biomed Mater Res B Appl Biomater, 68, 149-159.

Tan, KS; Qian, L; et al. (2006). The role of titanium surface topography on J774A.1 macrophage inflammatory cytokines and nitric oxide production. Biomaterials, 27, 5170-5177.

Tang, L. \& Eaton, JW. (1993). Fibrin(ogen) mediates acute inflammatory responses to biomaterials. J Exp Med, 178, 2147-2156.

Taxt-Lamolle, SF; Rubert, M; et al. (2010). Controlled electro-implementation of fluoride in titanium implant surfaces enhances cortical bone formation and mineralization. Acta Biomater, 6, 1025-1032.

Thomsen, P; Ericson, LE. (1985). Light and transmission electron microscopy used to study the tissue morphology close to implants. Biomaterials, 6, 421-424.

Thomsson, M; Esposito, M. (2008). A retrospective case series evaluating Branemark BioHelix implants placed in a specialist private practice following 'conventional' procedures. One-year results after placement. Eur J Oral Implantol, 1, 229-234.

Uusitalo, H ; Hiltunen, A ; et al. (2000). Expression of cathepsins B, H, K, L, and S and matrix metalloproteinases 9 and 13 during chondrocyte hypertrophy and endochondral ossification in mouse fracture callus. Calcif Tissue Int, 67, 382-390. 
Vercaigne, S; Wolke, JG; Naert, I. \& Jansen, JA. (1998). Bone healing capacity of titanium plasma-sprayed and hydroxylapatite-coated oral implants. Clin Oral Implants Res, 9, 261-271.

Vercaigne, S; Wolke, JGC; Naert, I. \& Jansen, JA. (2000). A histologicalevaluation of TiO2gritblasted and Ca-P magnetron sputter coated implants placed into the trabecular bone of the goat: Part 2. Clin Oral Implant Res, 11, 314-324.

Verheyen, CC; Dhert, WJ; Petit, PL; Rozing, PM. \& de Groot, K. (1993). In vitro study on the integrity of a hydroxylapatite coating when challenged with staphylococci. J Biomed Mater Res, 27, 775-781.

Wang, Y; Deng, Y; et al. (2008). SDF-1alpha/CXCR4-mediated migration of systemically transplanted bone marrow stromal cells towards ischemic brain lesion in a rat model. Brain Res, 1195, 104-112.

Weng, D; Hoffmeyer, M; Hurzeler, MB. \& Richter, EJ. (2003). Osseotite vs. machined surface in poor bone quality. A study in dogs. Clin Oral Implants Res,14, 703-708.

Wennerberg, A. \& Albrektsson, T. (2000). Suggested guidelines for the topographic evaluation of implant surfaces. Int J Oral Maxillofac Implants, 15, 331-344.

Wennerberg, A; Albrektsson, T; Ulrich, H. \& Krol, JJ. (1992). An optical three-dimensional technique for topographical descriptions of surgical implants. J Biomed Eng, 14, 412-418.

Wennerberg, A; Albrektsson, T; Andersson, B. \& Krol, JJ. (1995). A histomorphometric and removal torque study of screw-shaped titanium implants with three different surface topographies. Clin Oral Implants Res, 6, 24-30.

Wennerberg, A; Ektessabi, A; Albrektsson, T; Johansson, C. \& Andersson, B. (1997). A 1-year follow-up of implants of differing surface roughness placed in rabbit bone. Int $\mathrm{J}$ Oral Maxillofac Implants, 12, 486-494.

Wennerberg, A; Albrektsson, T; Johansson, C. \& Andersson, B. (1996). Experimental study of turned and grit-blasted screw-shaped implants with special emphasis on effects of blasting material and surface topography. Biomaterials, 17, 15-22.

Wennerberg, A; Albrektsson, T. \& Andersson, B. (1996). Bone tissue response to commercially pure titanium implants blasted with fine and coarse particles of aluminum oxide. Int J Oral Maxillofac Implants, 11, 38-45.

Wennerberg, A. On the surface roughness and implant incorporation. Göteborg: Göteborg University; 1996.

West, JK; Clark, AE; Hall, MB. \& Turner, GE. (1990). In vivo bone-bonding study of Bioglass-coated titanium alloy. In Yamamuro T, Hench LL, Wilson J. editors. Handbook of bioactive ceramics, Vol I, CRC Press: Boca Raton FL, 161-166.

Willmann, G. (1997). Bioceramics, 10, 353-356.

Wilson, J; Pigoit, HH; Schoen, FT. \& Hench, LL. (1981). Toxicology and biocompatibility of bioglass. J Biomed Mater Res, 15, 805.

Xie, XH; Yu, XW; Zeng, SX; Du, RL; Hu, YH; Yuan, Z; Lu, EY; Dai, KR. \& Tang, TT. (2010). Enhanced osteointegration of orthopaedic implant gradient coating composed of bioactive glass and nanohydroxyapatite. J Mater Sci Mater Med, 21, 2165-2173.

Xia, W; Lindahl, C; Lausmaa, J; Borchardt, P; Ballo, A; Thomsen, P. \& Engqvist, H. (2010). Biomineralized strontium-substituted apatite/titanium dioxide coating on titanium surfaces. Acta Biomater, 6, 1591-1600. 
Yang, GL; He, FM; Hu, JA; Wang, XX. \& Zhao, SF. (2009). Effects of biomimetically and electrochemically deposited nano-hydroxyapatite coatings on osseointegration of porous titanium implants. Oral Surg Oral Med Oral Pathol Oral Radiol Endod. 107, 782-9.

Yang, Y; Kim, KH. \& Ong, JL. (2005). A review on calcium phosphate coatings produced using a sputtering process--an alternative to plasma spraying. Biomaterials, 26, 32737.

$\mathrm{Yu}, \mathrm{J}$; Li, M; et al. SDF-1/CXCR4-mediated migration of transplanted bone marrow stromal cells towards areas of heart myocardial infarction via activation of PI3K/Akt. J Cardiovasc Pharmacol.

Zhang, E. \& Zou, C. (2009). Porous titanium and silicon-substituted hydroxyapatite biomodification prepared by a biomimetic process: characterization and in vivo evaluation. Acta Biomater, 5, 1732-1741. 


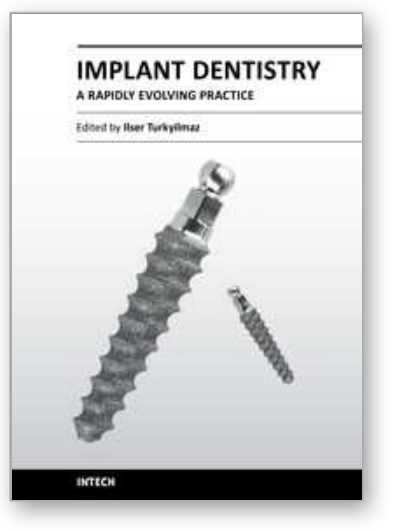

\author{
Implant Dentistry - A Rapidly Evolving Practice \\ Edited by Prof. Ilser Turkyilmaz
}

ISBN 978-953-307-658-4

Hard cover, 544 pages

Publisher InTech

Published online 29, August, 2011

Published in print edition August, 2011

Implant dentistry has come a long way since Dr. Branemark introduced the osseointegration concept with endosseous implants. The use of dental implants has increased exponentially in the last three decades. As implant treatment became more predictable, the benefits of therapy became evident. The demand for dental implants has fueled a rapid expansion of the market. Presently, general dentists and a variety of specialists offer implants as a solution to partial and complete edentulism. Implant dentistry continues to evolve and expand with the development of new surgical and prosthodontic techniques. The aim of Implant Dentistry - A Rapidly Evolving Practice, is to provide a comtemporary clinic resource for dentists who want to replace missing teeth with dental implants. It is a text that relates one chapter to every other chapter and integrates common threads among science, clinical experience and future concepts. This book consists of 23 chapters divided into five sections. We believe that, Implant Dentistry: A Rapidly Evolving Practice, will be a valuable source for dental students, post-graduate residents, general dentists and specialists who want to know more about dental implants.

\title{
How to reference
}

In order to correctly reference this scholarly work, feel free to copy and paste the following:

Ahmed M. Ballo, Omar Omar, Wei Xia and Anders Palmquist (2011). Dental Implant Surfaces Physicochemical Properties, Biological Performance, and Trends, Implant Dentistry - A Rapidly Evolving Practice, Prof. Ilser Turkyilmaz (Ed.), ISBN: 978-953-307-658-4, InTech, Available from:

http://www.intechopen.com/books/implant-dentistry-a-rapidly-evolving-practice/dental-implant-surfacesphysicochemical-properties-biological-performance-and-trends

\section{INTECH}

open science | open minds

\section{InTech Europe}

University Campus STeP Ri

Slavka Krautzeka 83/A

51000 Rijeka, Croatia

Phone: +385 (51) 770447

Fax: +385 (51) 686166

www.intechopen.com

\section{InTech China}

Unit 405, Office Block, Hotel Equatorial Shanghai

No.65, Yan An Road (West), Shanghai, 200040, China

中国上海市延安西路65号上海国际贵都大饭店办公楼405单元

Phone: +86-21-62489820

Fax: $+86-21-62489821$ 
(C) 2011 The Author(s). Licensee IntechOpen. This chapter is distributed under the terms of the Creative Commons Attribution-NonCommercialShareAlike-3.0 License, which permits use, distribution and reproduction for non-commercial purposes, provided the original is properly cited and derivative works building on this content are distributed under the same license. 